\begin{tabular}{|l|c|c|c|}
\hline Natura Somogyiensis & $\mathbf{5}$ & $255-278$ & Kaposvár, 2003 \\
\hline
\end{tabular}

\title{
Adatok a Látrányi Puszta Természetvédelmi Terület kétszárnyú (Diptera) faunájához
}

\author{
TÓTH SÁNDOR
}

\author{
H-8420 Zirc, Szćchenyi u. 2., Hungary
}

\section{TórH S.: Data to the fly fauna of the Látranyi Puszta Nature Conservation Area (Diptera)}

Abstract: In the years of 2000, 2001, and 2002, the author carried out a basic faunistical researches on the Diptera fauna of the area announced to be protected in 1992. During the survey, the occurrence of 305 taxa of 25 Diptera families was reported. Among the relatively interesting species, the following ones are worth mentioning: Nephrotoma scurra (Meigen, 1818), Ptychoptera albimana (Fabricius, 1787), Chaoborus flavicans (Meigen, 1830), Systoechus gradatus (Wiedemann, 1820), Villa humilis (Ruthe, 1831), Callicera aenea (Fabricius, 1781), Pelecocera tricincta Mcigen, 1822, Merodon clavipes (Fabricius, 1781), Eristalis abusiva Collin, 1931. Upon the results of these researches, it can be ascertained that in the Diptera fauna of the area, elements which are typical to the sandy steppes of the Transdanubian and Great Plain regions occur in abundance. Key words: Diptera, faunistical survey, ecology, nature conservation

\section{Bevezetés}

A Duna-Dráva Nemzeti Parkhoz tartozó Látrányi Puszta Természetvédelmi Terület Somogy megye külső-somogyi részén, Látrány település és a Tetves-patak között húzódó homokbuckákon, illetleg a buckák közötti nedvesebb réteken található. Területe 223 ha, tengerszint feletti magassága 116,8 és 143,1 m között változik. Éghajlata mérsékelten meleg és mérsékelten nedves. A területet borító változatos növénytársulások közül, a kétszárnyúak szempontjából, elsősorban a száraz homoki gyepfoltok, a homoki sztyeprétek, valamint a nedvesebb kaszálórétek jelentősebbek. A vizsgált objektumon a szárazföldi élöhelyek uralkodnak, azonban több évig tartó csapadékos időszakokban néhány ponton kialakulnak olyan többé-kevésbé nedves vagy vizes élöhelyek, melyekben amfibikus kétszárnyúak lárvái is kifejlödhetnek. Ezeket a mélyebb fekvésü foltokat az elmúlt két évben többnyire csak kiszáradt nádasok, füzesek és égeresek jelezték. 2000ben még viszonylag szép, bár kisebb vizes élöhelyek voltak a Visz település előtti útelágazásban (út melletti árkok, égerliget stb.), ahol a tömérdek csípöszúnyog lárva mellett, több vizhez kötődő Diptera (Tabanidae, Stratiomyidae, Syrphidae stb.) lárvája is gyüjthető volt. A természetvédelmi terület egyetlen állandó jellegü, jelentös vizes élőhelye a terület határán folyó, lassan áramló és dús vegetációjú szakaszokkal rendelkező Tetvespatak, melyben ugyancsak sok Diptera (elsősorban Chironomidae) lárvája fejlődik.

A terület kutatását Dr. Ábrahám Levente osztályvezető (Somogy Megyei Múzeum Természettudományi Osztálya) kezdeményezte, valamint szervezte, öt illeti köszönet a kutatásba való bekapcsolódás lehetőségéért, valamint a terepmunka anyagi támogatásáért.

A kutatás célja a természetvédelmi terület kétszárnyú (Diptera) faunájának, a lehetőségek keretein belül történő alapállapot felmérése volt, melyet a rendelkezésre álló viszonylag rövid idő miatt csak kis mértékben sikerült megoldani.

A kétszárnyúak kutatottsága Somogy megyében összességében jónak mondható, de más állatcsoportokhoz hasonlóan területileg közel sem egyenletes. Ez egyértelmüen ki- 
derül a közelmúltban a Somogy Megyei Múzeum kiadásában és Dr. Ábrahám Levente szerkesztésében megjelent kötetnek (ÄвARAнÁM 2001) a Dipterákkal foglalkozó dolgozataiból, melyek közül csak a jelen munka keretébe tartozó családokat tartalmazó publikációkat soroljuk fel (MAJER 2001a, 2001b, 2001c, 2001d, TóTH 2001a, 2001b, 2001c, $2001 \mathrm{~d}, 2001 \mathrm{e}, 2001 \mathrm{f}, 2001 \mathrm{~g}, 2001 \mathrm{~h}$ ). Említést érdemel még egy viszonylag nagyobb, 7 családhoz tartozó, 373 faj korábban nem publikált somogyi adatait tartalmazó dolgozat (TóTH 2002), mely viszonylag jelentös mértékben járul hozzá a somogyi táj faunájának jobb megismeréséhez. A legjobban feltárt, ennek következtében a legismertebb terület a Dráva mente, elsősorban a Duna-Dráva Nemzeti Park, a Boronka-melléki Tájvédelmi Körzet, a Zselic, valamint részben régebbi publikációk alapján, a Somogy megyéhez tartozó Balaton partvidék faunája. Az eddig rendelkezésre álló publikációk azonban a Látrányi Puszta Természetvédelmi Területéről nem tartalmaznak dipterafaunisztikai adatot.

\section{Anyag és módszer}

Módszer tekintetében a hasonló jellegü felmérések során használt eszközök és módszerek alkalmazására került sor. A kétszárnyú imágók megfogására $30 \mathrm{~cm}$ átmérőjü keretre erősített tüll anyagból készült lepkeháló módosított változata, a lárvák gyüjtésére erösebb molnárszita-szövetből összeállított vízi háló szolgált. A munkát a viszonylag kevés személyes gyüjtés mellett jól kiegészítette, és egyben eredményesen segítette az alkalmi Malaise-csapda használata. A Balaton déli partján folyó csípőszúnyog kutatás lehetővé tette a terület gyakoribb felkeresését, esetekenként csupán a Malaise-csapda egyegy félnapra történő felállítását.

A munka során preparált kevés Diptera a Somogy Megyei Múzeum Természettudományi Osztályának gyüjteményét gyarapítja.

A kutatás céljára a program szervezöje által kijelölt 6 mintaterület a kétszárnyú-fauna felmérése szempontjából is alkalmasnak bizonyult, de ezek mellett célszerü volt a terület más pontjain is gyüjtéseket végezni. Ezek a következők voltak: 7. sz. terület (csapadékos időjárású években vizes élőhely Visz település közelében a TT határán). 8. sz. terület (dús növényzetü virágos rét Lászlótanya és a müút között). 9. sz. terület (dús növényzetü nedvesebb rét a Tetves-patak mentén Tukoratanya környékén). A mintaterületek vázlatos térképét az 1 . ábra szemlélteti.

\section{Eredmények}

A munka során gyüjtött anyag feldolgozásával 23 kétszárnyú családhoz tartozó 305 taxonnak a területen való elöfordulását tekinthetjük igazoltnak. Az erre vonatkozó számszerü adatokat az 1. táblázat tartalmazza.

A táblázat adataiból kiderül, hogy az eddigi gyüjtések alapján az 5. sz. mintaterület Diptera-faunája bizonyult a legfajgazdagabbnak, ahonnan 135 taxon előfordulását sikerült igazolni. Ez a "fajgazdagság" nyilvánvalóan csupán viszonylagos, további kétszárnyú családok rendszeres kutatása feltehetően ettől eltérő eredményt mutatna. A második helyen a 4. sz. mintaterület áll 115 fajjal, majd ezt követi a 8 . sz. mintaterület 110 fajjal. Említést érdemel még a negyedik helyen álló 1 . sz. mintaterület ( 99 faj), valamint a 82 fajjal képviselt 2. sz. mintaterület. Az eredményeket százalékos arányban kördiagram (4. ábra) mutatja be. 


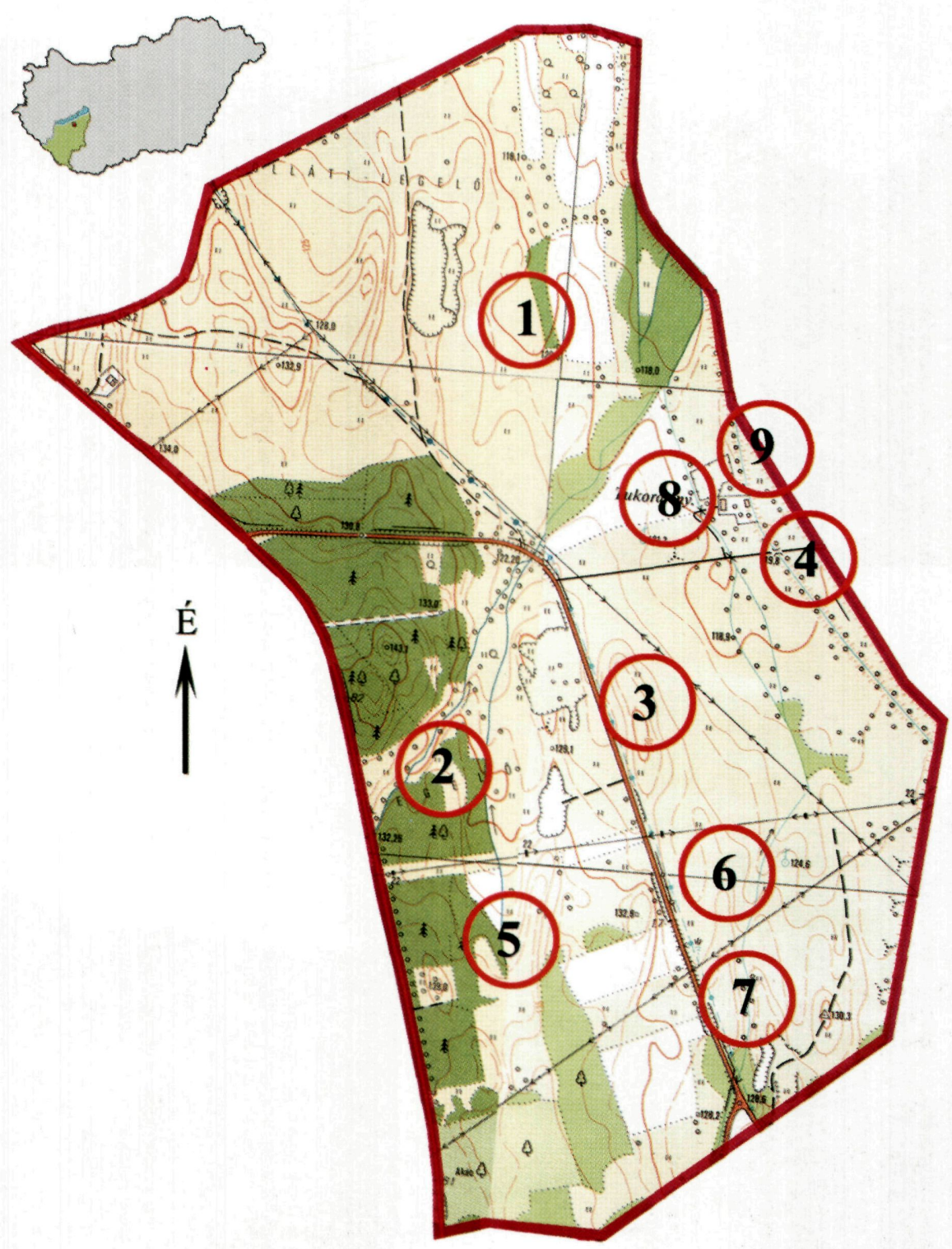




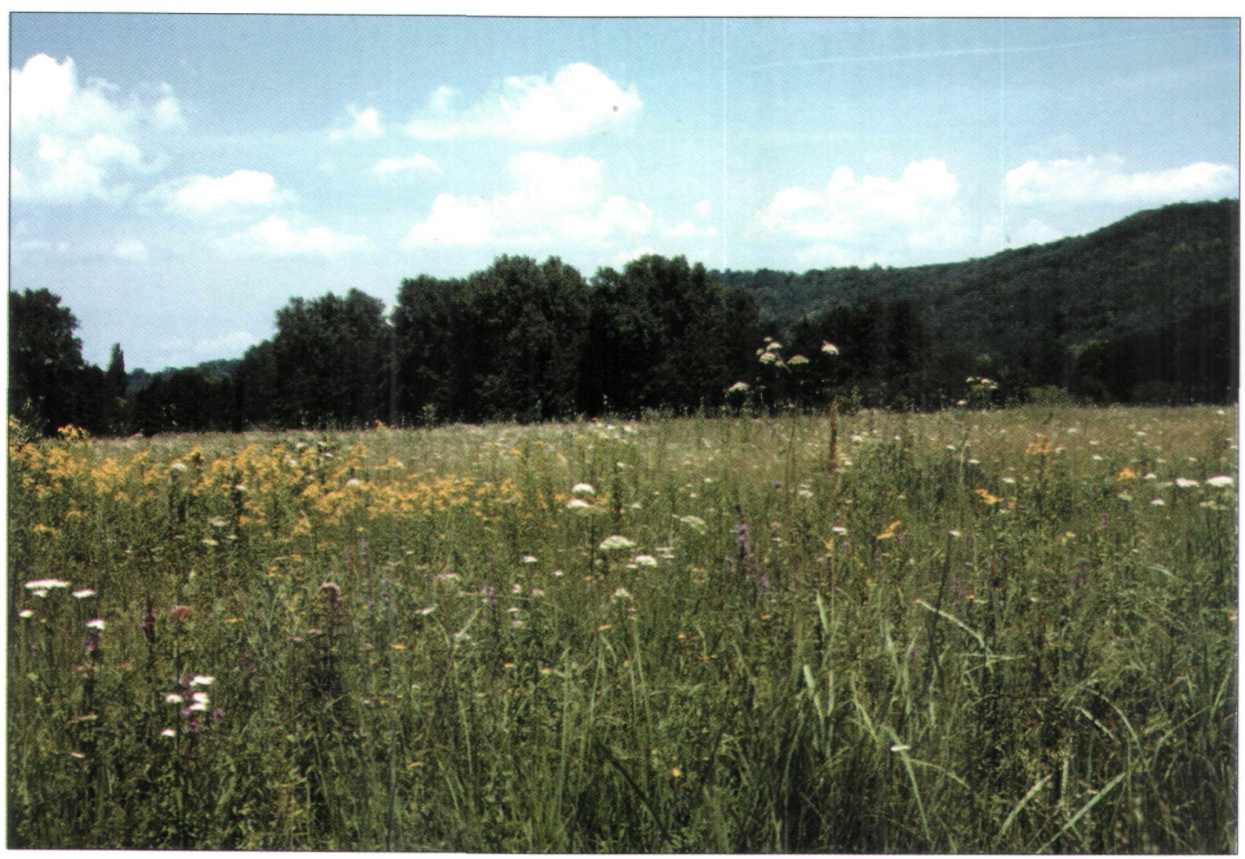

2. ábra: A 4. számú mintaterület

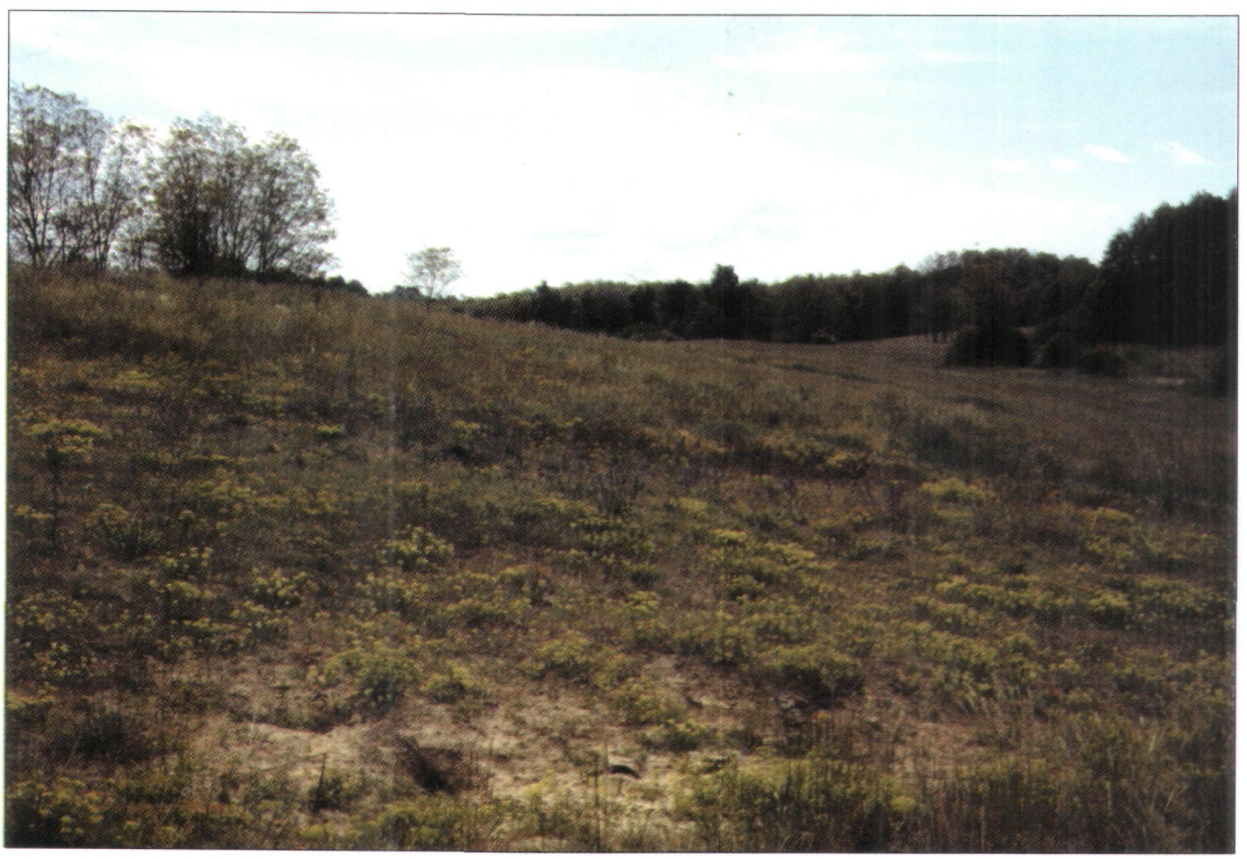

3. ábra: Az 5. számú mintaterület 
A vizsgált terület kétszárnyúi zömmel a mindenfelé megtalálható gyakori vagy közönséges fajok közül kerülnek ki. Kisebb számban előfordulnak azonban közöttük viszonylag ritkának nevezhető, illetőleg kisebb-nagyobb mértékben valamilyen élőhelyhez (pl. homokpusztai gyep) vagy részben táplálékukon keresztül meghatározott növényekhez kötődő taxonok is. A növények közül elsősorban a homokpusztákra jellemző pusztai kutyatej (Euphorbia sequieriana) emelhető ki, mely különösen nagy számban csalogatja a zengőlegyeket. Részben e növényhez, részben a homokhoz kötődik a terület egyik érdekesebb zengőlegye, a Merodon clavipes is. Már az eddigi eredményekből is kitünik, hogy a helyi kétszárnyú fauna bizonyos hasonlóságot mutat a Dunántúlon a Barcsi Borókás TK, a fenyőfői erdeifenyves-borókás, illetőleg az Alföld néhány homokvidékének, elsősorban a Kiskunságnak a faunájához. A már említett zengőlégyen kívül ide sorolható legalább részben a Callicera aenea, a Pelecocera tricincta és a Spilomyia diophthalma, a pöszörlegyek közül a Micomitra stupida, a Systoechus gradatus és a Villa humilis, a tőröslegyek közül a Cliorismia ardea, vagy a kockás húslegyek közé tartozó Taxigramma heteroneurum és a Paragusina elegantula. Vizes élöhelyeken fejlődő kétszárnyúak közül ritkasága miatt érdemel említést a Ptychoptera albimana redősszúnyog, a Chaoborus flavicans bojtosszúnyog, a Nephrotoma scurra lószúnyog, valamint a Spathiophora hydromyzina ürüléklégy.

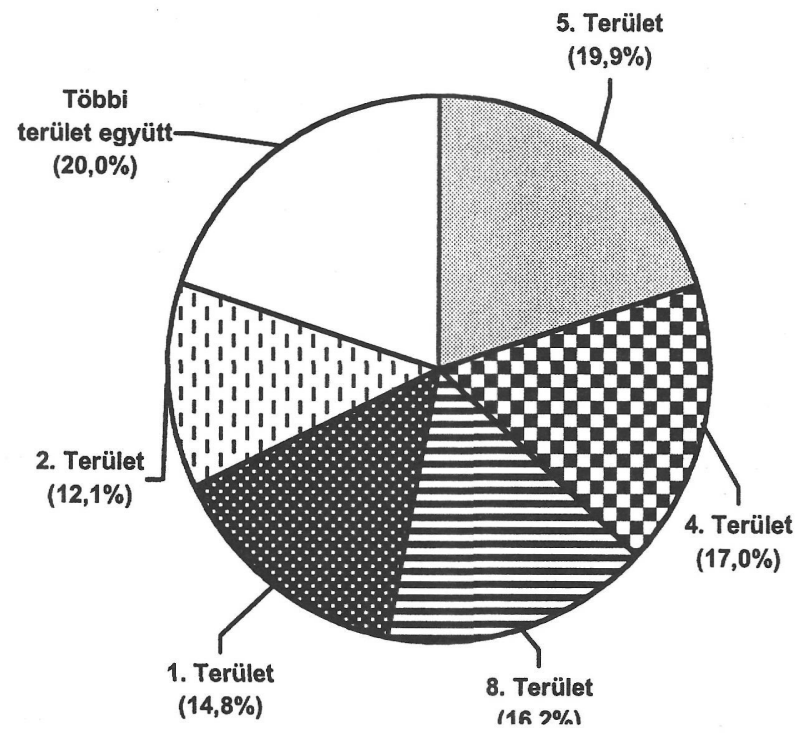

4. ábra: A Látrányi Puszta Természetvédelmi Terület kétszárnyú-faunájánakösszetétele a mintaterületeken előkerült fajok száma alapjản, százalékos arányban kifejezve 


\section{1. táblázat: A Látrányi Puszta Természetvédelmi Terület kétszárnyú (Diptera) faunájának számszerü kutatási eredményei}

Jelmagyarázat:

Összes (a táblázat fcjlćcénck oszlopában) $=$ Azt mutatja, hogy a család fajai hány

mintaterületen kerültek clö.

Összesen (a táblázat alsó sorában) = Azt mutatja meg, hogy az egyes mintaterületeken

összesen hány faj került clö, illetőleg a vizsgált családok hazai ćs a TT területén gyüjtött fajait összegezi.

M. O. = A család magyarországi ismert fajainak száma.

L. TT. = A család a Látrányi Puszta Természetvédelmi Területen kimutatott fajainak száma.

$\%=\mathrm{Az}$ cgycs családokból kimutatott taxonok a hazai fajszámhoz viszonyitott \%-os aránya.

\begin{tabular}{|c|c|c|c|c|c|c|c|c|c|c|c|c|c|c|}
\hline \multirow[b]{2}{*}{ S.sz. } & \multirow[b]{2}{*}{ Kutatott család } & \multicolumn{9}{|c|}{ Mintaterületek/fajszám } & \multirow[b]{2}{*}{ Összes } & \multirow[b]{2}{*}{ M.o. } & \multirow[b]{2}{*}{ L. TT. } & \multirow[b]{2}{*}{$\%$} \\
\hline & & 1. & 2. & 3. & 4. & 5. & 6. & 7. & 8. & 9. & & & & \\
\hline 1. & Bibionidae (Bársonylegyek) & 1 & 3 & 2 & 2 & 2 & 1 & & 4 & & 7 & 18 & 4 & 22.2 \\
\hline 2. & Ptychopteridae (Redõs szúnyogok) & & & & 2 & & & 2 & 1 & 1 & 4 & 7 & 2 & 28.6 \\
\hline 3. & Chaoboridae (Bojtos szúnyogok) & & & & & & & 2 & & 1 & 2 & 4 & 2 & 50 \\
\hline 4. & Culicidae (Csípõszúnyogok) & 3 & 4 & 4 & 11 & 5 & 2 & 10 & 7 & 3 & 9 & 46 & 19 & 41.3 \\
\hline 5. & Tipulidae (Lószúnyogok) & 4 & 4 & 3. & 10 & 4 & 3 & & 7 & 1 & 8 & 77 & 13 & 16.9 \\
\hline 6. & Limoniidae (Iszapszínyogok) & 5 & 3 & 3 & 9 & 1 & 1 & 4 & 4 & 4 & 9 & 116 & 15 & 12.9 \\
\hline 7. & T abanidae (Bögölyök) & 8 & 3 & & 7 & 9 & 1 & & 7 & & 6 & 60 & 15 & 25 \\
\hline 8. & Xylomyidae (nincs magyar nevük) & & 1 & & & 1 & & & & & 2 & 3 & 1 & 33.3 \\
\hline 9. & Stratiomyidae (Katonalegyek) & 7 & 4 & & 9 & 12 & & & 5 & & 5 & 58 & 17 & 29.3 \\
\hline 10. & Rhagionidae (Kószalegyek) & 1 & 1 & 2 & 4 & 3 & & & & & 5 & 26 & 4 & 15.4 \\
\hline 11. & Bombyliidae (Pöszörlegyek) & 8 & 5 & 1 & 2 & 11 & 1 & & 4 & & 7 & 69 & 16 & 23.2 \\
\hline 12. & Therevidae (Töröslegyek) & 2 & 1 & & & 4 & & & 1 & & 4 & 33 & 5 & 15.2 \\
\hline 13. & Syrphidae (Zengõlegyek) & 24 & 17 & 19 & 36 & 48 & 19 & 2 & 41 & 3 & 9 & 367 & 82 & 22.3 \\
\hline 14. & Conopidae (Fejeslegyek) & 7 & 2 & 3 & 3 & 11 & 1 & & 1 & & 7 & 53 & 13 & 24.5 \\
\hline 15. & Tephritidae (Fúrólegyek) & 2 & 3 & 1 & 2 & 2 & 1 & & 2 & & 7 & 110 & 11 & 10 \\
\hline 16. & Scatophagidae (Ürüléklegyek) & 2 & 1 & 1 & 2 & 1 & 1 & 1 & 3 & 1 & 9 & 32 & 7 & 21.9 \\
\hline 17. & Muscidae (Igazi legyek) & 5 & 6 & & 1 & 3 & 4 & & 2 & 1 & 7 & 210 & 12 & 5.71 \\
\hline 18. & Calliphoridae (Fémeslegyek) & 4 & 5 & 2 & 1 & 3 & 4 & & 2 & & 7 & 56 & 9 & 16.1 \\
\hline 19. & Sarcophagidae (Húslegyek) & 2 & 2 & 1 & 1 & 1 & 2 & & 2 & & 7 & 130 & 7 & 5.38 \\
\hline 20. & Gast erophilidae (Gyomorbagócsok) & & 2 & & & & & & & & 1 & 5 & 1 & 20 \\
\hline 21. & Oestridae (Orrbagócsok) & 1 & & & & & & & & & 1 & 4 & 1 & 25 \\
\hline 22. & Hippoboscidae (Kullancslegyek) & & 1 & & & 1 & & & & & 2 & 11 & 2 & 18.2 \\
\hline 23. & T achinidae (Fürkészlegyek) & 13 & 14 & 8 & 13 & 13 & 9 & & 17 & & 7 & 433 & 47 & 10.9 \\
\hline Össz & esen: & 99 & 82 & 50 & 115 & 135 & 50 & 21 & 110 & 15 & & 1928 & 305 & 15.8 \\
\hline
\end{tabular}

\section{A fajok felsorolása a gyüjtési adatokkal}

A faunisztikai adatközlö fejezet a hasonló jellegü dolgozatok összeállításánál szokásos alapadatokat tartalmazza.

Röviditések:

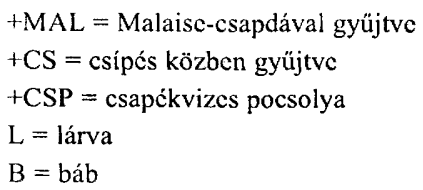

$\mathrm{B}=$ báb

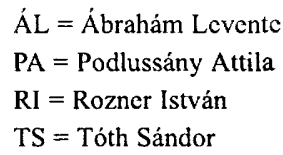




\section{Alrend: Nematocera}

\section{Bibionidae}

A 18 hazai fajból 4 került elő a területen.

Dilophus febrilis (Linnaeus, 1758)

1. sz. mintaterület: 2001.09 .15 ., 30", TS - 3. sz. mintaterület: $2002.04 .26 ., 1 \sigma 2 \%$, TS - 8. sz. mintaterület: 2000.05 .05 ., 10̛ 2ᄋ, TS, +MAL.

Bibio marci (Linnacus, 1758)

2. sz. mintaterület: $2002.04 .16 ., 4 \sigma^{\circ} 10$, TS - 3 . sz. mintatcrület: 2002.04 .26 ., $60^{*} 2$ 2 , TS - 4. sz. mintaterület: 2000.05 .05 ., $70^{\circ} 4$ \% , TS - 6. sz. mintaterület: $2002.04 .26 ., 1 \sigma 5 \%$, TS - 8. sz. mintaterület: 2002.04.19., 50' 2ᄋ , TS, +MAL.

Bibio hortulanus (Linnaeus, 1758)

2. sz. mintaterület: $2002.04 .16 ., 1 \sigma^{\prime} 1 \%$, TS, +MAL - 5. sz. mintatcrülct: 2001.06.14., 30'5\% , TS, +MAL; 2002.04.26., 2ᄋ , TS - 8. sz. mintaterület: 2000.05.05., 20 4\% , TS, +MAL.

Bibio johannis (Linnaeus, 1767)

2. sz. mintaterület: $2002.04 .16 ., 10$, TS - 4, sz. mintaterület: $2001.06 .15 ., 2 \sigma^{\circ} 10$, TS - 5. sz. mintaterület: $2001.06 .14 ., 1 \sigma$, TS, +MAL - 8. sz. mintaterület: 2002.04.19., 3\%, TS, +MAL.

\section{Ptychopteridae}

Kisebb kétszárnyú család, a 7 ismert hazai faj közül 2 került elő a természetvédelmi területen. Ritkasága miatt kiemelhető a Ptychoptera albimana.

Ptychoptera albimana (Fabricius, 1787)

4. sz. mintaterület: 2001.05 .29 ., 10 20, TS - 7. sz. mintaterülct: 2000.04.10, 30" 1o , TS - Látrányi puszta TT: 2000.04.11., 10" ÁL. Ritka, eddig csak a Börzsöny, a Bükk, a Kőszegi-hegység és a Vértes cgy-cgy pontján gyüjtöttćk.

Ptychoptera contaminata (Linnacus, 1758)

4. sz. mintaterület: $2001.05 .29 ., 6 \sigma^{\circ} 20$, TS; 2001.07.22., 50"3@, TS - 7. sz. mintatcrülct: 2000.04.10., 10 3\% , TS; 2002.04.20., 10 5\% , TS 8. sz. mintaterület: 2001.06.06., 3ᄋ, TS, +MAL - 9. sz. mintaterület: $2002.04 .19 ., 10^{*} 1 \%$, TS.

\section{Chaoboridae}

Kis kétszárnyú család, a 4 ismert hazai fajból kettő elökerült a területen, közülük a Chaoborus flavicans viszonylag ritka.

Chaobortus crystallinus (De Geer, 1776)

7. sz. mintaterület: $2000.04 .10 ., 3 \mathrm{~L}, \mathrm{TS}$; 2002.04.20., 2 L, TS - 9. sz. mintaterület:
2002.04.19, 10' 5o , TS.

Chaoborus flavicans (Meigen, 1830)

7. sz. mintaterület: $2002.04 .20,1$ L, TS.

\section{Culicidae}

Az ismert hazai taxonok száma 46 (45 faj + 1 alfaj). Annak ellenére, hogy a vizsgált területen kevés a vizes élöhely, 19 faj elöfordulását sikerült igazolni. Közülük viszonylagos ritkasága miatt a Culex territans, a Culiseta morsitans és az Uranotaenia unguiculata érdemel említést.

Aedes cantans (Meigen, 1818)

5. sz. mintatcrület: $2002.04 .26 ., 10$, TS - 7. sz mintaterülct: 2000.04 .10 ., 8 L, $3 \mathrm{~B}$, TS.

Aedes caspius (Pallas, 1771)

1. sz. mintaterület: 2000.07 .21 ., 1\%, TS, +CS 3. sz. mintaterület: $2001.09 .16 ., 3 \sigma^{\circ} 2 \%$, TS - 5. sz. mintaterülct: 2001.06.14., 10 2ᄋ, TS, +MAL.

Aedes cataphylla Dyar, 1916

5. sz. mintaterület: 2002.04 .26$, , 1Q , TS - 7. sz. mintaterülct: 2000.04 .10 ., $28 \mathrm{~L}, 6 \mathrm{~B}$, TS.

Aedes cinereus Mcigen, 1818

3. sz. mintaterület: 2001.09.16., 20, TS, +CS 4. sz. mintaterület: $2000.05 .05 ., 18, \mathrm{TS},+\mathrm{CS}-7 . \mathrm{sz}$. mintaterület: $2000.04 .10 ., 4$ L, TS - 8. sz. mintaterület: 2001.06.06., 1\% 2Q , TS, +MAL.

Aedes excrucians (Walker, 1856)

4. sz. mintaterület: 2000.05 .05 ., $10 \% 10$, TS - 7 . sz. mintaterület: $2000.04 .10 ., 2$ L, TS.

Aedes flavescens (Müllcr, 1764)

1. sz. mintaterület: 2001.09.15., 1Q , TS - 5. sz. mintaterület: 2001.06.15., 1\%, TS

Aedes geniculatus Olivier, 1791)

2. sz. mintaterület: 2000.08 .07 , 1@ , TS - 4. sz. mintatcrület: 2001.07.27., 10 1\%, TS, +MAL.

Aedes rusticus (Rossi, 1790)

2. sz. mintaterület: $2002.04 .16 ., 30^{\circ} 10, \mathrm{TS}-7$. sz. mintatcrülct: 2000.04 .10 ., $6 \mathrm{~L}$, TS - 8. sz. mintaterülct: 2002.04.19., 10", TS, +MAL.

Aedes sticticus (Meigen, 1838)

4. sz. mintaterület: $2001.06 .15 ., 1075 \%$, TS - 5 . sz. mintaterülct: 2001.06.14., 10 , TS, +MAL - 7. sz. mintaterülct: $2000.04 .10 ., 3 \mathrm{~L}$, TS.

Aedes vexans (Meigen, 1830)

1. sz. mintaterület: 2001.09.15., 1\% , TS, +CS 3. sz. mintaterület: $2001.09 .16 ., 1 \%$, TS, +CS - 4. sz. mintatcrület: 2000.05 .05 ., $3 \sigma^{\circ} 1 \%$, TS; 2001.08.20., 2 , , TS - 6. sz. mintaterület: 2001.10.14., 1Q , TS - 8 . sz. mintaterület: 2001.07.05., 20'5\%, TS, +MAL. Anopheles claviger (Mcigen, 1804)

2. sz. mintaterület: 2002.04.16., 1\%, TS, +CS - 
7. sz. mintaterület: 2000.04 10., 8 L, 2 B, TS.

Anopheles maculipennis Meigen, 1818

4. sz. mintaterület: 2001.05.11., 1\%, TS - 9. sz. mintaterület: 2001.07 .22 ., 23 L, +CSP.

Anopheles messeae Falleroni, 1926

7. sz. mintaterület: 2002.04 .20 , 1\%, TS - 8. sz. mintaterület: 2002.04.26., 1\%, TS, +MAL.

Anopheles plumbeus Stephens, 1828

4. sz. mintaterület: 2001.08 .20 , 10, TS, +CS 8. sz. mintaterület: 2001.06.06., 10, TS, +MAL.

Culex pipiens Linnaeus, 1758

2. sz. mintaterület: $2002.04 .16 ., 2 \wp$, TS, +MAL 3. sz. mintaterület: 2002.04 .26 ., 3ᄋ , TS - 4. sz. mintaterület: 2001.07.27., 20 9\%, TS, +MAL - 6. sz. mintaterület: 2001.10 .14 ., $4 \sigma^{\circ} 2 \propto$, TS - 8. sz. mintaterület: 2001.07.05., 60 4\%, TS, +MAL - 9. sz. mintaterület: 2001.07.22., $16 \mathrm{~L}, 5 \mathrm{~B}$, +CSP - Látrányi puszta TT: 2001.07.05., $34 \mathrm{~L}, 8 \mathrm{~B}$, +CSP.

Culex territans Walker, 1856

7. sz. mintaterület: 2000.04 .10 ., 3 L, TS.

Culiseta annulata (Schrank, 1776)

4. sz. mintaterület: 2001.07.27., $1 \sigma^{\circ} 2 q$, TS, +MAL - 7. sZ. mintaterület: 2002.04.20., 6 L, TS - 9. sz. mintaterület: 2002.04.19., 2Q , TS.

Culiseta morsitans (Theobald, 1901)

4. sz. mintaterület: $2000.05 .05 ., 10$, TS.

Uranotaenia unguiculata Edwards, 1913

4. sz. mintaterület: 2001.06 .15 ., 1@ , TS, +CS 8. sz. mintaterület: 2001.06.06., 10 1\% , TS, +MAL.

\section{Tipulidae}

Magyarország Tipulidae-faunája még nincs alaposabban kikutatva, a publikált fajok száma 77. Somogy megyéből mindössze 30 taxon előfordulásáról tudunk (ТóTH 2001a), ez azonban nyilván csak kisebb hányada a tényleges faunának. A Látrányi Puszta Természetvédelmi Terület jelenleg ismert lószúnyog-faunáját csupán 13 faj alkotja. Közülük elsösorban a viszonylag ritka Nephrotoma scurra érdemel említést.

Ctenophora ornata Mcigen, 1818

4. sz. mintaterület: $2001.06 .15 ., 10^{\prime \prime}$ TS.

Dictenidia bimaculata (Linnaeus, 1761)

1. sz. mintaterület: 2000.07 .21 , 10", TS - 4. sz. mintaterület: $2001.07 .27 ., 2 \sigma^{\circ} 1 \%$, TS, +MAL.

Nephrotoma aculeata (Loew, 1871)

4. sz. mintaterület: 2001.06.15., 2Q, TS - 5. sz. mintaterület: 2001.08 .20 ., 10", TS

Nephrotoma analis (Schummel, 1833)

4. sz. mintaterület: 2000.05 .05 ., 10", TS - 5. sz. mintaterület: 2001.06.14., 10 1\% , TS, +MAL - 8. sz. mintaterület: 2001.07 .05 ., 20, TS, +MAL.

Nephrotoma appendiculata (Pierre, 1919)

4. sz. mintaterület: 2000.05 .05 ., $60^{*} 8 \%$, TS; 2001.05.11, $3 \sigma^{*} 2$ \% , TS - 6. sz. mintaterület: 2002.04.26., 10", TS - 8. sz. mintaterület: 2001.07.05., 140 6\% , TS, +MAL. Egyike leggyakoribb lószúnyogjainknak, föleg nevesebb réteken néha tömegesen jelenik meg.

Nephrotoma scurra (Meigen, 1818)

2. sz. mintaterület: $2002.04 .16 ., 1 \sigma^{\prime} 30$, TS - 3 . sz. mintaterület: 2002.04.26., 1Q, TS - 5. sz. mintaterület: 2001.06.14., 20 5\%, TS, +MAL; 2001.06.15., 10 1\%, TS. A Palearktikum nagy részében elterjedt lószúnyog. Magyarország kevćs helyén, clsősorban homokvidékeken található. A Barcsi-borókásban és a Fenyöföi-ösfenyvesben az eredeifenyves-borókás tisztásain él. A Látrányi Puszta Tcrmészetvédelmi Terület lószúnyog-faunájának egyik színezö eleme.

Nigrotipula nigra (Linnaeus, 1758)

2. sz. mintaterület: 2000.08 .07 ., 1\%, TS - 4. sz. mintaterület: $2000.05 .05 ., 30 \% 1 \%$, TS - 5. sz. mintaterület: 2002.04.26., 1申, TS - 8. sz. mintaterület: 2001.06.06., 20 1\% , TS, +MAL.

Tanyptera atrata (Linnaeus, 1758)

4. sz. mintaterület: 2000.05 .05 , 1Q , TS.

Tipula fascipennis Mcigen, 1818

1. sz. mintaterület: $2000.07 .21 ., 1 \sigma^{*} 1$, TS - 8 . Sz. mintaterület: $2002.04 .26 ., 10$, TS, +MAL.

Tipula lunata Linnaeus, 1758

4. sz. mintaterület: 2001.06.15., 10", TS - 8. sz. mintaterület: 2001.06.06., 1\%, TS, +MAL.

Tipula oleracea Linnaeus, 1758

1. sz. mintaterület: $2001.09 .15 ., 4 \sigma^{\prime \prime} 1 \%$, TS -3 . sz. mintaterület: 2002.04.26., 20", TS - 4. sz. mintatcrület: 2000.05.05., 10*3 3 , TS - 6. sz. mintaterület: 2001.10.14., 1\%, TS - 8. sz. mintaterület: 2001.06.06., 10 3o, TS, +MAL.

Tipula orientalis Lackschcwitz, 1930

1. sz. mintaterület: 2001.09 .15 ., 20", TS - 2. sz. mintaterület: $2002.04 .16 ., 50^{\prime} 2 \%$, TS - 3. sz. mintaterület: $2001.09 .16 ., 2 \sigma^{\circ}$, TS - 8. sz. mintaterület: 2002.04.19., 20 1\%, TS, +MAL - 9. sz. mintaterület: 2002.04.19., 10', TS.

Tipula paludosa Meigen, 1830

2. sz. mintaterület: $2000.08 .07 ., 1 \%$, TS - 4. sz. mintaterület: $2000.05 .05 ., 2 \sigma \times 1 q$, TS - 6. sz. mintaterület: $2002.04 .26 ., 10$, TS.

\section{Limoniidae}

Magyarország Limoniidae-faunája még alaposabb kutatásra vár, az eddig publikált 
116 faj valószínüleg meg sem közelíti a ténylegesen előfordulókét. Még kedvezőtlenebb a helyzet Somogy megyében, mivel onnan korábban mindössze 11 fajt közöltek (TóTH 2001b), ami nem éri el az ismert hazai fauna 10\%-át. Ebből a szempontból viszonylag jónak mondható a Látrányi Puszta Természetvédelmi Terület kutatottsága, ahonnan a rövid idő és célzottnak nem nevezhető gyüjtőmunka ellenére, 15 faj elöfordulására van adatunk. Ezzel egyúttal 16-re emelkedett a Somogyból nyilvántartott fajok száma.

\section{Dicranomyia modesta (Meigen, 1818)}

1. sz. mintaterület: 2000.07 .21 ., 10, TS - 3. sz. mintaterület: $2001.09 .16 ., 1 \sigma^{\circ}$, TS - 4. sz. mintaterület: $2001.05 .11 ., 2 \sigma^{\circ} 1 \%$, TS.

Epiphragma ocellare (Linnaeus, 1761)

4. sz. mintaterület: $2000.05 .05 ., 3 \sigma^{\circ} 1 \%$, TS - 7 . sz. mintaterület: 2002.04 .20 , $2 \sigma^{\circ}$, TS - 8. sz. mintaterület: 2002.04 .26 ., 1申, TS, +MAL - 9. sz. mintaterület: 2002.04.19., 2@ , TS.

Eutonia barbipes (Meigen, 1804)

4. sz. mintaterület: 2001.05 .11 , $10 \% 4$, TS - 9. sz. mintaterület: 2002.04.19., 4ᄋ , TS.

Gonomyia tenella (Meigen, 1818)

2. sz. mintaterület: 2002.04.16., 10', TS - 8. sz. mintaterület: 2002.04.19., 20 10, TS, +MAL.

Limonia phragmitidis (Schrank, 1781)

1. sz. mintaterület: 2001.09.15., 10", TS - 4. sz. mintaterület: $2001.06 .15 ., 2 \sigma^{\circ}$, TS.

Limnophila pictipennis (Meigen, 1818)

4. sz. mintaterület: 2000.05 .05 ., 30', TS - 8. sz. mintaterület: 2002.04.26., $1 \sigma^{\circ} 1 \%$, TS, +MAL.

Limnophila schranki Oosterbroek, 1992

7. sz. mintaterület: $2002.04 .20 ., 1005$, TS - 9. sz. mintaterület: 2002.04 .19 ., 20', TS.

Limonia albifrons (Meigen, 1818)

4. sz. mintaterület: 2001.05 .11 ., 1Q, TS - 6. sz. mintaterület: 2002.04.26., 10, TS.

Metalimnobia bifasciata (Schrank, 1781)

1. sz. mintaterület: 2000.07 .21 ., 10', TS - 5. sz. mintaterület: 2001.08.20., 20*, TS.

Metalimnobia quadrimaculata (Linnaeus, 1761)

3. sz. mintaterület: 2001.09.16., 20', TS - 4. sz. mintaterület: 2001.08.20., 10", TS.

Molophilus obscurus (Meigen, 1818)

1. sz. mintaterület: 2001.09.15., 10, TS - 2. sz. mintaterület: $2000.08 .07 ., 1 \sigma$, TS.

Neolimnomyia nemoralis (Meigen, 1818)

4. sz. mintaterület: 2001.05.11., 10", TS - 8. sz. mintaterület: 2001.06.06., 20", TS, +MAL.
Phylidorea ferruginea (Meigen, 1818)

7. sz. mintaterület: 2002.04 .20 , 10 , TS - 9. sz. mintaterület: $2002.04 .19 ., 10$, TS.

Symplecta hybrida (Meigen, 1904)

1. sz. mintaterület: 2000.07 .21 ., 1002 , TS - 4 . sz. mintaterület: $2000.05 .05 ., 10$, TS.

Symplecta stictica (Meigen, 1818)

2. sz. mintaterület: 2002.04.16., $2 \sigma^{\circ} 1$ 1Q , TS - 3. sz. mintaterület: $2001.09 .16 ., 20$, TS - 7. sz. mintaterület: $2002.04 .20 ., 1 \sigma^{*}$, TS.

\section{Alrend: Brachycera}

\section{Tabanidae}

$\mathrm{Az}$ ismert hazai taxonok száma jelenleg kereken 60, melyek közül Somogyból 43 fajt közöltek (MAJER 2001), további 2 fajt tartalmaz egy újabb publikáció (TóTH 2002). A Látrányi Puszta Természetvédelmi Területről 15 taxont sikerült kimutatni.

Atylotus rusticus (Linnaeus, 1767)

2. sz. mintaterület: 2000.08 .07 , 1\%, TS - 4. sz. mintaterület: $2001.07 .27 ., 20$, TS, +MAL - 8. sz. mintaterület: $2000.05 .05 ., 1 \%$, TS, +MAL.

Chrysops caecutiens (Linnaeus, 1758)

5. sz. mintaterület: 2001.08.20., 2Q, TS - 6. sz. mintaterület: 2002.04 .26 ., 1\%, TS.

Chrysops relictus Meigen, 1820

1. sz. mintaterület: 2000.07 .21 ., 2Q, TS - 4. sz. mintaterület: 2001.05.11., 10, TS.

Chrysops viduatus (Fabricius, 1794)

1. sz. mintaterület: 2001.05.29., 4\% , TS, +MAL - 5. sz. mintaterület: $2001.06 .15 ., 10$, TS - 8. sz. mintaterület: $2001.06 .06 ., 1 \sigma 3 \%$, TS, +MAL.

Hybomitra acuminata (Loew, 1858)

1. sz. mintaterület: $2001.05 .29 ., 10, \mathrm{TS},+\mathrm{MAL}$ - 8. sz. mintaterület: 2001.07.05., 10", TS, +MAL.

Hybomitra ciureai (Séguy, 1937)

1. sz. mintaterület: 2000.07 .21 ., 1Q, TS - 4. sz. mintaterület: 2001.06 .15 ., 4 Q , TS - 8. sz. mintaterület: 2001.07.05., 2@, TS, +MAL.

Tabanus autumnalis Linnaeus, 1761

4. sz. mintaterület: 2000.05 .05 , 1q, TS - 5. sz. mintaterület: 2001.07.05., 10 1\%, TS.

Tabanus bovinus Linnaeus, 1758

1. sz. mintaterület: 2001.05.29., 1ᄋ , TS, +MAL.

Tabanus bromius Linnaeus, 1758

1. sz. mintaterület: $2001.05 .29 ., 30$, TS, +MAL - 5. sz. mintaterület: 2001.06 .15 ., 1Q , TS - 8. sz. mintatcrület: 2001.07.05., 2ᄋ ,TS, +MAL.

Tabanus glaucopis Meigen, 1820

2. sz. mintaterület: $2000.08 .07 ., 1 \%$, TS - 4. sz. 
mintaterület: 2001.07.27., 1\%, TS, +MAL.

Tabanus maculicornis Zetterstedt, 1842

1. sz. mintaterület: 2000.07 .21 ., 4 , TS - 5. sz. mintaterület: $2001.06 .15 ., 1$,, TS -8 . sz. mintaterület: 2001.06.06., 2ᄋ, TS, +MAL.

Tabanus spodopterus Meigen, 1820

5. sz. mintaterület: 2001.06 .15 ., 1\%, TS.

Tabanus tergestinus Meigen, 1820

4. sz. mintaterület: 2000.05.05., 1Q, TS - 5. sz. mintaterület: 2001.06.14., 1९, TS, +MAL.

Haematopota pluvialis (Linnaeus, 1758)

1. sz. mintaterület: 2001.05.29., 7\% , TS, +MAL; 2001.09.15., 1\%, TS - 4. sz. mintaterület: 2001.07.27., 4@, TS, +MAL - 5. sz. mintaterület: 2001.05.11., 2९, TS; 2001.06.14., 8९, TS, +MAL; 2001.08.20., $1 \sigma 4 \%$, TS - 8. sz. mintaterület: 2000.05.05., 5\%, TS, +MAL; 2001.07.05., 9\% , TS, +MAL

Therioplectes gigas (Herbst, 1787)

2. sz. mintaterület: 2000.08 .07 ., 1Q, TS - 5. sz. mintaterület: 2001.07.05., 10, TS.

\section{Xylomyidae}

Kis kétszárnyú család, a 3 ismert hazai fajból 1 nagyon gyakori a vizsgált területen is elökerült.

Solva marginata (Meigen, 1820)

2. sz. mintaterület: $2000.08 .07 ., 1 \sigma^{\circ} 8 \mathrm{O}$, TS - 5. sz. mintaterület: 2002.04.26., 1申, TS; 2001.08.20., 2 Q , TS.

\section{Stratiomyidae}

Közepes nagyságú kétszárnyú család, a nyilvántartott hazai fajok száma jelenleg 58, közülük Somogyból 42-őt közöltek (Majer 2001). A Látrányi Puszta Természetvédelmi Területen eddig 17 faj került elő.

\section{Actina chalybea Meigen, 1804}

1. sz. mintaterület: $2001.04 .26 ., 2 \sigma^{\prime \prime} 1$ \% , RI - 4 . sz. mintaterület: $2001.05 .11 ., 8 \sigma^{\circ} 2 \uparrow$, TS - 5. sz. mintaterület: 2001.04.26., 10 2ᄋ , PA; 2002.04.26., 4\%", 1申, TS - 8. sz. mintaterület: 2000.05.05., 40 1\%, TS, +MAL.

Beris chalybata (Forster, 1761)

2. sz. mintaterület: 2002.04 .16 ., 20, TS - 8. sz. mintaterület: 2002.04.19., 30\%, TS, +MAL.

Beris clavipes (Linné, 1767)

4. sz. mintaterület: 2000.05 .05 ., 1Q , TS - 5. sz. mintaterület: 2001.06.15., 20", TS.

Beris fuscipes Meigen, 1820

1. sz. mintaterület: 2000.07 .21 ., 1\%, TS - 4. sz. mintaterület: 2001.05.11., 2Q, TS.
Chloromyia formosa (Scopoli, 1763)

1. sz. mintaterülct: 2001.05 .29 ., $2 \sigma^{\prime} 30$, TS, +MAL - 4. sz. mintaterület: 2000.05.05., 3@ , TS - 5 . sz. mintaterület: 2001.05 .11 ., 1\%, TS; 2001.06.14., $30 \% 9$, TS, +MAL - 8. sz. mintaterület: 2001.07.05., 1060 , TS, +MAL.

Lasiopa calva (Meigen, 1822)

1. sz. mintaterület: 2000.07 .21 ., 2 Q , TS - 2. sz. mintaterület: $2000.08 .07 ., 10$, TS - 5. sz. mintaterület: 2001.06.15., TS.

Microchrysa polita (Linnaeus, 1758)

4. sz. mintaterület: $2001.06 .15 ., 10 \%$, TS - 5. sz. mintaterület: $2001.08 .20 ., 2 \sigma^{\prime} 4$ ᄋ , TS.

Nemotelus pantherinus (Linnaeus, 1758)

1. sz. mintatcrülct: 2001.05 .29 ., $30^{\circ} 1 \%$, TS, +MAL - 5. sz. mintatcrület: 2001.06.15., 10, TS.

Odontomyia tigrina (Fabricius, 1775)

4. sz. mintaterület: $2000.05 .05,1 \sigma^{*} 4$ \& , TS; 2001.07.27., 20'4\% , TS, +MAL - 8. sz. mintaterület: 2001.06.06., 2Q, TS, +MAL.

Oplodontha viridula (Fabricius, 1775)

1. sz. mintaterület: $2000.07 .21 ., 5 \sigma 1 \%$, TS - 4 . sz. mintaterület: 2000.05.05., $1 \sigma^{\prime \prime} 5 \%$, TS; 2001.07.27., 4@, TS, +MAL - 8. sz. mintaterület: 2001.07.05., 30' 10, TS, +MAL.

Oxycera leonina (Panzer, [1798])

2. sz. mintaterület: $2000.08 .07 ., 1 \%$, TS - 5. sz. mintaterület: 2001.07.05., 1\%', TS.

Pachygaster atra (Panzer, [1798])

5. sz. mintaterület: 2002.04.26., 10", TS; 2001.08.20., 20 8\%, TS.

Pachygaster leachi (Curtis, 1824)

1. sz. mintaterület: 2000.07 .21 ., 10', TS - 5. sz. mintaterület: $2001.06 .15 ., 2$, , TS.

Sargus bipunctatus (Scopoli, 1763)

2. sz. mintaterület: $2000.08 .07 ., 1 \%$, TS.

Sargus cuprarius (Linnaeus, 1758)

1. sz. mintaterület: $2001.09 .15 ., 1$, TS - 5. sz. mintaterület: $2001.08 .20 ., 10$, TS.

Stratiomys longicornis (Scopoli, 1763)

4. sz. mintaterület: $2000.05 .05,2 q$, TS - 5. sz. mintaterület: 2001.07.05., 1\%, TS.

Stratiomys singularior (Harris, [1776])

4. sz. mintaterület: $2001.06 .15 ., 1 \%$, TS - 5. sz. mintaterület: $2001.06 .15 ., 10$, TS.

\section{Rhagionidae}

Kisebb kétszárnyú család, az ismert hazai fajok száma 12. Somogyból 9 fajt közöltek (MAJER 2001), közülük a vizsgált területen midössze 4 került elö.

Chrysopilus aureus (Meigen, 1804)

4. sz. mintaterület: 2000.05 .05 ., 1申, TS - 5. sz. 


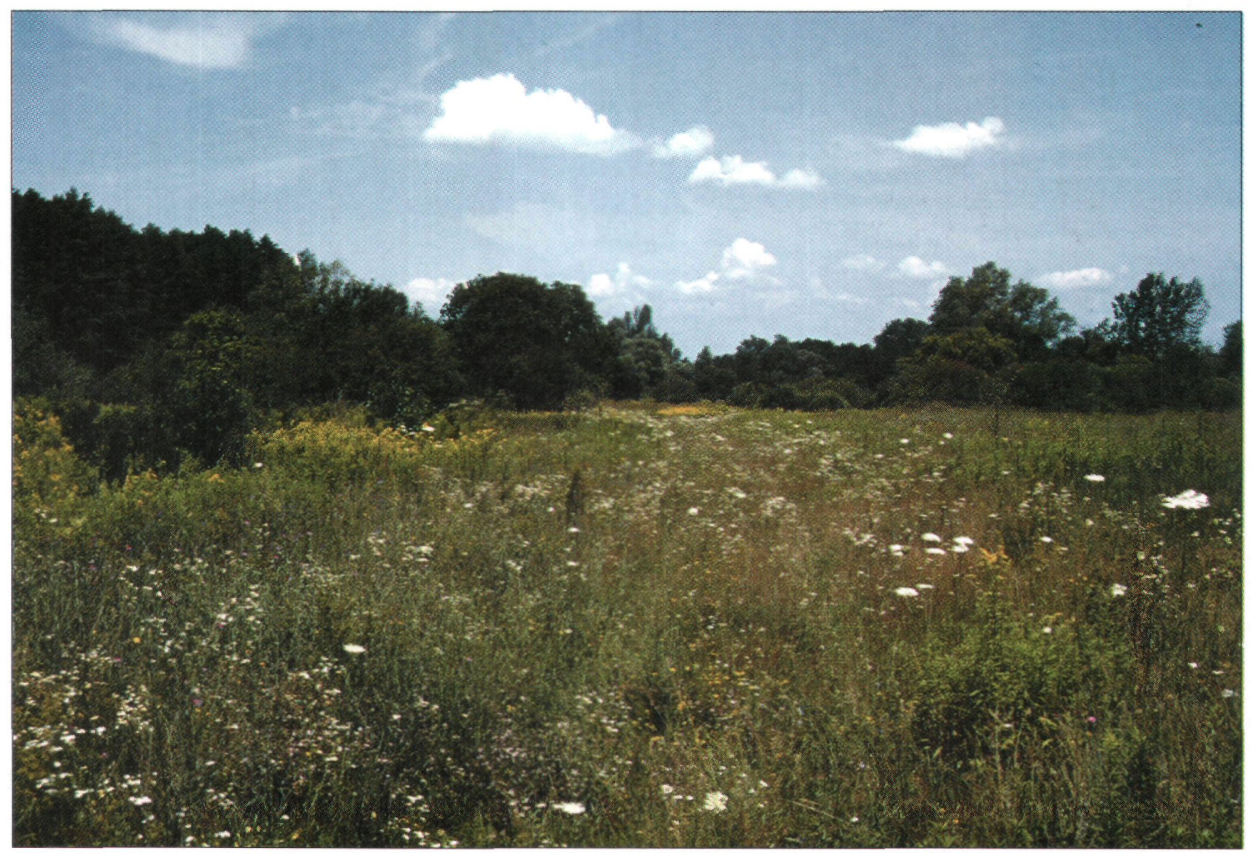

5. ábra: A 8. számú mintaterület részlete

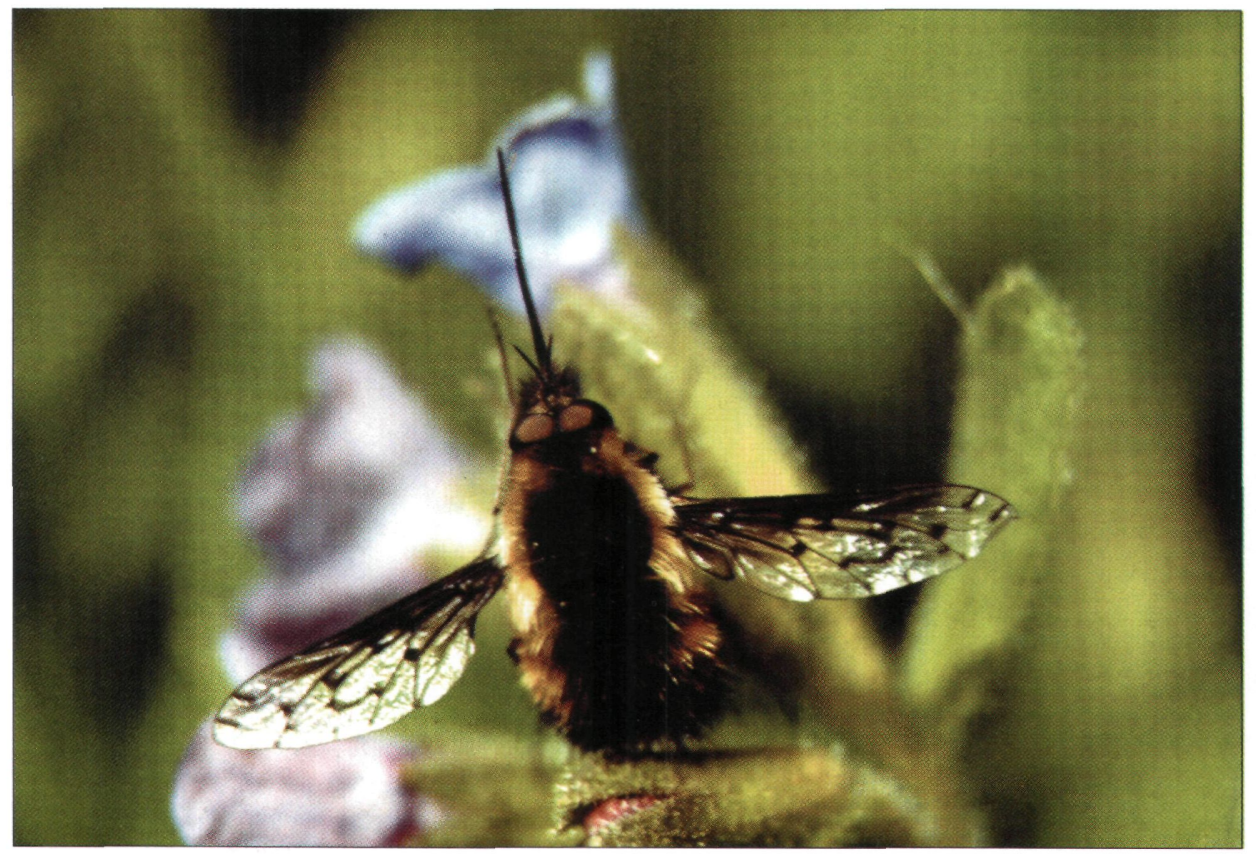

6. ábra: Bombylius medius 


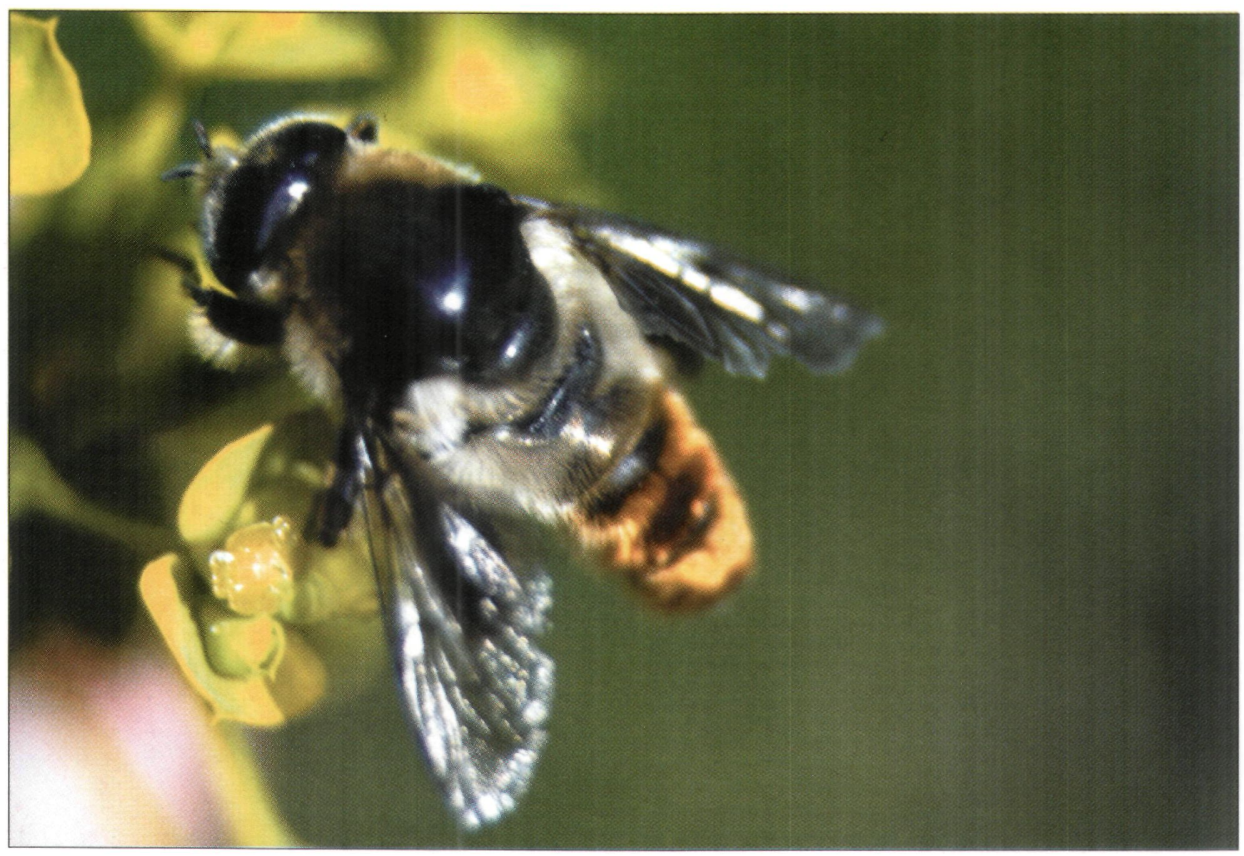

7. ábra: Merodon clavipes

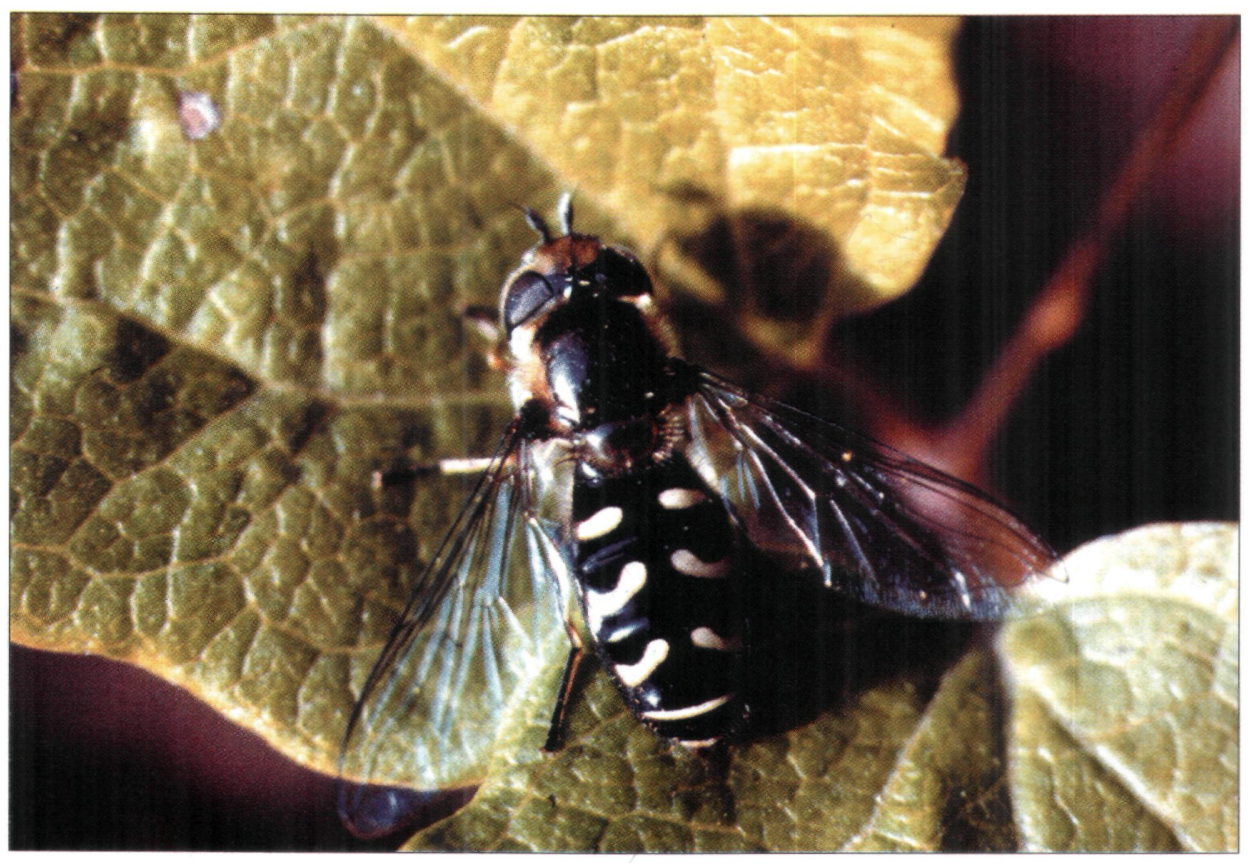

8. ábra: Scaeva pyrasti 
mintaterület: 2001.05.11., 20" 1\% , TS.

Chrysopilus auratus (Fabricius, 1805)

2. sz. mintaterület: $2002.04 .16 ., 1 \%$, TS, +MAL - 3. sz. mintaterület: 2002.04 .26 ., 20,, TS - 4. sz. mintaterület: 2001.05.11., 10", TS.

Rhagio scolopaceus (Linnacus, 1758)

4. sz. mintaterület: 2000.05 .05 ., 10", TS - 5. sz. mintaterület: $2001.06 .14 ., 1 \%$, TS, +MAL.

Rhagio tringarius (Linnaeus, 1758)

1. sz. mintaterület: 2000.07 .21 ., $2 \sigma^{\prime \prime} 10$, TS - 3 . sz. mintaterülct: 2002.04 .26 , 1\%, TS - 4. sz. mintaterület: 2001.05.11., 1 $\sigma^{\prime} 3$ o , TS - 5. sz. mintaterület: 2001.06.14., 10\%, TS, +MAL.

\section{Bombyliidae}

Közepes légycsalád, az ismert hazai fajok száma jelenleg 69. Somogyból jelenleg 23 fajt tartunk nyilván (TóTH 2001). A Látrányi Puszta Természetvédelmi Területen eddig 16 taxon került elö. Figyelemreméltó a viszonylag ritka Systoechus gradatus tömeges elöfordulása az 5 . sz. mintaterület homokhátján, valamint a szintén homokvidékekre jellemző, ugyancsak ritka Villa humilis jelenléte.

Anthrax leucogaster Wiedemann in Meigen, 1820

1. sz. mintaterület: 2000.07 .21 ., 1\%, TS.

Bombylius ater Scopoli, 1763

1. sz. mintatcrület: 2001.05.29., 1\%, TS, +MAL -

5. sz. mintaterület: 2002.04.26., 1\%, TS.

Bombylius cinerascens Mikan, 1796

1. sz. mintaterület: 2001.05 .29 , $2 \sigma^{\circ} 5 \%$, TS, +MAL - 5. sz. mintaterület: 2001.06.15., 1\% , TS.

Bombylius fimbriatus Meigen, 1820

2. sz. mintaterület: 2002.04.16., 1ㅇ, TS - 4. sz. mintaterület: 2001.05.11., 10, TS.

Bombylius major Linnacus, 1758

2. sz. mintaterület: 2002.04 .16 ., 30'2\%, TS - 3 . sz. mintaterület: $2002.04 .26 ., 2 \wp$, TS - 6. sz. mintaterület: 2002.04.26., 1\%, TS - 8. sz. mintaterület: 2002.04.19., 1申, TS, +MAL - Látrányi puszta TT: 1992.04.17., 10', ÁL.

Bombylius medius (Linnacus, 1758)

2. sz. mintaterület: 2002.04 .16 ., 10 , TS - 8. sz. mintaterület: $2000.05 .05 ., 10$, TS, +MAL.

Bombylosoma minimum (Scopoli, 1772)

1. sz. mintatcrület: 2000.07 .21 ., 10", TS.

Conophorus virescens (Fabricius, 1787)

1. sz. mintaterület: $2001.05 .11 ., 1 \sigma^{\circ} 3$ o, TS - 5 . sz. mintaterület: 2001.06 .15 ., $3 \sigma^{\circ} 7 \%$, TS - 8. sz. mintaterület: $2001.06 .06 ., 1 \sigma 4 \% \mathrm{TS},+\mathrm{MAL}$.

Hemipenthes morio (Linnacus, 1758)

1. sz. mintaterület: 2000.07 .21 ., 2 Q , TS - 4. sz. mintaterület: $2001.07 .27 ., 1 \sigma^{\circ}, \mathrm{TS},+\mathrm{MAL}$ - 5. sz. mintaterület: $2001.06 .15 ., 10$, TS.

Lomatia sabaea (Fabricius, 1781)

1. sz. mintaterület: 2000.07 .21 ., 10', TS - 5. sz. mintaterület: 2001.06.14., 1९, TS, +MAL.

Micomitra stupida (Rossi, 1790)

5. sz. mintaterület: $2001.06 .15 ., 1 \%$, TS.

Phthiria canescens Loew, 1846

2. sz. mintaterület: 2000.08 .07 ., 10, TS - 5. sz. mintaterület: $2001.06 .15 ., 1 \%$, TS.

Systoechus ctenopterus (Mikan, 1796)

5. sz. mintaterület: 2001.07.05., 20"1@, TS.

Systoechus gradatus (Wiedemann, 1820)

5. sz. mintaterület: 2000.07 .21 ., $90^{\circ} 14 \%$, TS; 2001.06.14., 10 6\% , TS, +MAL; 2001.07.05., 260" 6 , , TS.

Villa hottentotta (Linnacus, 1758)

1. sz. mintaterület: 2000.07 .21 ., 1\%, TS; 2001.09.15., 10, TS - 5. sz. mintaterület: 2001.06.15., 10", TS - 8. sz. mintaterület: 2001.07.05., 1\%, TS, +MAL.

Villa humilis (Ruthe, 1831)

2. sz, mintaterület: 2000.08 .07 ., 20", TS - 5. sz. mintaterület: $2001.06 .15 ., 10^{\circ} 2$, TS.

\section{Therevidae}

Kisebb család, a Magyarországról kimutatott fajok száma 32, a Somogyból közölteké 12 (Тóтн 2001, 2002). A Látrányi puszta Természetvédelmi Területén 5 faj került elö.

Cliorismia ardea (Fabricius, 1794)

1. sz. mintaterület: 2001.05 .29 ., $30 \% 2 \%$, TS, +MAL - 5. sz. mintaterület: 2001.06.14., 1@ , TS, +MAL.

Thereva aurata Locw, 1854

5. sz. mintaterület: 2002.04.26., 10', TS.

Thereva cincta Mcigen, 1820

2. sz. mintaterület: 2000.08 .07 ., 3ㅇ , TS.

Thereva fulva (Meigen, 1804)

1. sz. mintaterület: 2000.07 .21 ., 2 ᄋ , TS - 5. sz. mintaterület: $2001.06 .14 ., 1 \%$, TS, +MAL.

Thereva plebeja (Linnaeus, 1758)

5. sz. mintaterület: 2001.08 .20 , 1\%, TS - 8. sz. mintaterület: $2001.07 .05 ., 1 \%$, TS, +MAL.

\section{Syrphidae}

A zengőlegyek a nagyobb kétszárnyú családok egyikét alkotják, a jelenleg nyilvántartott hazai fajok száma 367. Somogy a zengölegyek szempontjából viszonylag jól kutatottnak nevezhetö, a megyéböl 226 fajt közöltek (TóTH 2001). A Látrányi 
Puszta Természetvédelmi Terület zengölégy-faunája is viszonylag gazdagnak tekinthető, mivel már az aránylag rövid kutatási periódus alatt 82 faj jelenlétét sikerült kimutatni. Az érdekesebb elemek között említhető taxonok: Callicera aenea, Eristalis abusiva, Merodon clavipes, Pelecocera tricincta.

Anasimyia transfuga (Linnaeus, 1758)

4. sz. mintaterület: 2000.05 .05 , 1\%, TS - 8. sz. mintaterület: 2001.07 .05 , $1 \sigma^{\circ} 4 \mathrm{Q}$, TS, +MAL.

Callicera aenea (Fabricius, 1781)

6. sz. mintatcrület: 2000.05.05., 10, TS, Cratacgus-on gyüjtve.

Chalcosyrphus nemorum (Fabricius, 1805)

5. sz. mintaterület: 2002.04 .26 ., 10, TS - 8. sz. mintaterület: 2000.05.05., 1\%, TS, +MAL.

Cheilosia barbata Loew, 1857

1. sz. mintaterület: 2000.07 .21 , 1Q , TS - 4. sz. mintaterület: $2001.07 .27,1 \sigma$, TS, +MAL - 5. sz. mintatcrülct: $2001.07 .05 ., 10 \% 10$, TS.

Cheilosia flavipes (Panzer, 1798)

2. sz. mintaterülct: 2002.04 .16 , 10, TS - 5. sz. mintaterület: 2001.05 .11 ., 2ᄋ, TS - 8. sz. mintaterület: 2000.05.05., 1Q, TS, +MAL.

Cheilosia impressa Loew, 1840

1. sz. mintaterület: $2000.07 .21 ., 1 \sigma^{\prime} 5$ o , TS - 4 . sz. mintaterület: $2001.07 .27 ., 1 \sigma 3 \%$, TS, +MAL - 6 . sz. mintaterület: 2002.04.26., 10", TS.

Cheilosia mutabilis (Fallén, 1817)

8. sz. mintaterület: 2001.07.05., 2ᄋ , TS, +MAL - 9. sz. mintaterület: $2002.04 .19 ., 10$, TS.

Cheilosia proxima (Zctterstedt, 1843)

5. sz. mintaterület: 2001.04.26., 10 , PA.

Cheilosia scutellata (Fallén, 1817)

1. sz. mintaterület: 2001.09.15., 10" 1Q, TS - 2 .

sz. mintaterület: $2000.08 .07 ., 1 \%$, TS.

Cheilosia soror (Zetterstedt, 1843)

4. sz. mintaterület: 2001.08 .20 ., $2 \sigma^{\circ} 1$ 1\%, TS - 8 . sz. mintaterület: 2001.07.05., 1९ , TS, +MAL.

Cheilosia variabilis (Panzer, 1798)

1. sz. mintaterület: 2001.04.26, 1\%, PA.

Chrysotoxum arcuatum (Linnaeus, 1758)

1. sz. mintaterület: 2001.10.05., 1\%, RI.

Chrysotoxum cautum (Harris, 1776)

5. sz. mintaterület: $2001.04 .26 ., 10^{\circ}$, PA.

Chrysotoxum bicinctum (Linnacus, 1758)

1. sz. mintaterülct: 2001.05 .29 ., $1 \sigma^{*} 5 \%$, TS, +MAL - 5. sz. mintaterület: 2001.07.05., 1Q , TS.

Chrysotoxum vernale Loew, 1841

4. sz. mintaterülct: 2000.05 .05 ., 10, TS - 5. sz. mintaterület: 2001.04.26., 1\% , PA; 2001.05.11., 1\% ,
TS - 8. sz. mintaterület: 2000.05.05., 20'10, TS, +MAL. Dasysyrphus albostriatus (Fallén, 1817)

4. sz. mintaterület: $2001.06 .15 ., 1 \%$, TS - 5. sz. mintaterület: 2001.07 .05 ., 10", TS - 8. sz. mintaterület: 2001.06.06., 2\% , TS, +MAL.

Dasysyrphus tricinctus (Fallén, 1817)

1. sz. mintaterület: 2000.07 .21 , 1申, TS - 3. sz. mintaterület: 2001.09.16., 1\%", TS.

Dasysyrphus venustus (Meigen, 1822)

4. sz. mintaterület: 2001.05 .11 ., $2 \sigma^{*} 1 \%$, TS - 5 . sz. mintaterület: 2002.04 .26 ., 1@, TS - 8. sz. mintaterület: $2000.05 .05 ., 3 \sigma^{\circ} 1 \%$, TS, +MAL.

Didea fasciata Macquart, 1834

4. sz. mintaterület: $2000.05 .05 ., 10$, TS.

Epistrophe melanostoma (Zetterstedt, 1843)

4. sz. mintaterület: $2001.07 .27 ., 1$, , TS, +MAL - 6. sz. mintaterület: $2000.05 .05 ., 2 \varnothing$, TS, Crataeguson gyüjtve - 8. sz. mintaterület: 2002.04.26., 10", TS, +MAL.

Epistrophe nitidicollis (Meigen, 1822)

1. sz. mintaterület: 2000.07 .21 ., 2q, TS - 3. sz. mintaterület: 2001.09 .16 ., 1९, TS - 4. sz. mintaterület: 2001.07.27., 10"3o, TS, +MAL - 5. sz. mintaterület: 2001.08 .20 ., $1 \sigma$, TS - 8. sz. mintaterület: 2001.06.06., 3o , TS, +MAL.

Episyrphus balteatus (De Geer, 1776)

1. sz. mintaterület: 2001.05.29., 2ᄋ , TS, +MAL; 2001.09.15., $1 \sigma 4 \%$, TS - 2. sz. mintaterület: 2002.04.16., 3ᄋ , TS, +MAL - 3. sz. mintaterülct: 2001.09.16., 2ᄋ, TS - 4. sz. mintaterület: 2001.05.11., $1 \sigma^{*} 4 \propto$, TS - 5. sz. mintaterület: 2001.06.14., $20 \%$ 8 , TS, +MAL; 2001.07.05., 50 2Q , TS - 6. sz. mintaterület: 2001.10.14., 3Q , TS - 8 . sz. mintaterület: 2001.06.06., 30 9ᄋ, TS, +MAL; 2002.04.26., I申, TS, +MAL.

Eristalinus aeneus (Scopoli, 1763)

2. sz. mintaterület: $2002.04 .16 ., 1$, $\mathrm{TS},+\mathrm{MAL}$ -4. sz. mintaterület: 2001.07.27., 10,, TS, +MAL - 6 . sz. mintaterület: $2000.05 .05 ., 1 \%$, TS, Crataegus-on gyüjtve - 7. sz. mintaterület: 2002.04.20., 1\%, TS.

Eristalinus sepulchralis (Linnacus, 1758)

2. sz. mintatcrület: $2000.08 .07 ., 2 \sigma$, TS - 5. sz. mintaterület: 2001.07 .05 ., $1 \sigma^{\circ} 4$ ᄋ , TS.

Eristalis abusiva Collin, 1931

1. sz. mintaterület: 2001.05.29., 1ф, TS, +MAL 5. sz. mintaterület: $2001.05 .11 ., 10$, TS.

Eristalis arbustorum (Linnacus, 1758)

1. sz. mintaterület: 2000.07 .21 ., $2 \sigma^{\circ} 7 \%$, TS 2001.09.15., 3ᄋ, TS - 3. sz. mintaterület: 2001.09.16., $1 \sigma^{\prime} 6 \%$, TS - 5. sz. mintaterület: 2001.06.14., 10"6\% , TS, +MAL; 2001.07.05., 20" 
1Q , TS - 8. sz. mintaterület: 2002.04.26., 10", TS, +MAL. Eristalis interrupta (Poda, 1761)

5. sz. mintaterület: $2001.06 .15 ., 10$, TS - 6. sz. mintaterület: 2000.05.05., $1 \sigma^{\prime 2} 2 \%$, TS, Crataegus-on gyüjtve - 8. sz. mintaterület: 2001.06.06., $2 \sigma^{*} 4$ \% , TS, +MAL.

Eristalis tenax (Linnacus, 1758)

1. sz. mintaterület: 2001.09.15., $40^{\circ} 1 \%$, TS - 5 . Sz. mintaterület: 2001.07.05., $6 \sigma^{*} 4 Q$, TS; 2002.04.26., 1\%, TS - 6. sz. mintaterület: 2001.10.14., $5 \sigma^{\circ} 2 \%$, TS - 7. sz. mintaterület: 2002.04.20., 2ᄋ, TS - 8. sz. mintaterület: 2002.04.19., 1\%, TS, +MAL.

Eumerus strigatus (Fallén, 1817)

2. sz. mintaterület: 2000.08 .07 , 10\%, TS - 5. sz. mintaterület: 2001.06 .15 ., 30\%, TS - 8. sz. mintaterület: 2001.06.06., 10 2ᄋ, TS, +MAL.

\section{Eumerus tricolor (Fabricius, 1798)}

1. sz. mintaterület: 2001.05.29., 2Q , TS, +MAL.

Eupeodes corollae (Fabricius, 1794)

1. sz. mintaterület: $2001.09 .15 ., 20^{\circ} 60$, TS - 3 . sz. mintaterület: 2001.09 .16 ., 2ᄋ , TS - 4. sz. mintaterület: 2001.06 .15 ., $4 Q$, TS - 5. sz. mintaterület: 2002.04.26., 1\%, TS - 6. sz. mintaterület: 2000.05.05., 1ф, TS, Crataegus-on gyüjtve.

Eupeodes luniger (Meigen, 1822)

3. sz. mintaterület: $2002.04 .26 ., 10$, TS - 4, sz. mintaterület: 2001.08 .20 ., 3o , TS - 5. sz. mintaterület: 2001.06.14., 1申, TS, +MAL.

Ferdinandea cuprea (Scopoli, 1763)

5. sz. mintaterület: 2001.07 .05 ., 1\%, TS - 6. sz. mintatcrület: 2000.05.05., 1\%, TS, Crataegus-on gyüjtve

Helophilus pendulus (Linnacus, 1758)

3. sz. mintaterület: $2001.09 .16 ., 10 \%$ 3o , TS - 4 . sz. mintaterület: 2000.05 .05 ., 30", TS - 8. sz. mintaterület: 2001.07.05., 1\%, TS, +MAL.

Helophilus trivittatus (Fabricius, 1805)

1. sz. mintaterület: 2000.07 .21 , 10", TS - 4. sz. mintaterület: $2001.07 .27 ., 1 \%$, TS, +MAL.

Heringia heringi (Zetterstedt, 1843)

8. sz. mintaterület: $2000.05 .05 ., 10 \%$, TS, +MAL. Melanogaster nuda (Macquart, 1829)

4. sz. mintaterülct: $2001.05 .11 ., 80^{\circ} 13 \circ$, TS - 8 . sz, mintatcrület: $2001.06 .06 ., 3 \sigma 8 \mathrm{O}, \mathrm{TS},+\mathrm{MAL}$.

Melanostoma mellinum (Linnaeus, 1758)

1. sz. mintaterület: 2001.04.26., 1\%, PA; 2001.09.15., 7\%, TS; 2001.10.05., 1\%, RI - 3. sz. mintaterülct: 2001.09 .16 , 2Q , TS - 5. sz. mintaterület: 2001.04.26., 2Q , PA; 2001.06.14., 30 9\% , TS, +MAL - 6. sz. mintatcrület: 2001.10.14., 1申 , TS - 8 . sz. mintaterület: 2001.07.05., 3\% , TS, +MAL - 9. sz. mintaterület: 2002.04.19., 4Q , TS - Látrányi puszta TT: 1999.07.25., 3\%" 4Q , RI.

Melanostoma scalare (Fabricius, 1794)

2. sz. mintaterület: 2002.04 .16 ., $2 q$, TS - 4. sz. mintaterület: 2001.05 .11 ., $10 \% 3 \%$, TS - 5. sz. mintaterület: 2001.04.26., 1申 , PA; 2002.04,26., 1\%, TS.

Meliscaeva auricollis (Meigen, 1822)

1. sz. mintaterület: 2001.04.26., 10, PA.

Merodon avidus (Rossi, 1790)

1. sz. mintaterület: 2001.05 .29 ., $2 \sigma^{*} 1 \%$, TS, +MAL - 5. sz. mintaterület: 2001.06.14., 60 3\%, TS, +MAL; 2001.06.15., 10, TS.

Merodon clavipes (Fabricius, 1781)

1. sz. mintaterület: $2001.05 .29 ., 1 \%$, TS, +MAL - 2. sz. mintaterület: 2001.05.29., 70'1Q, TS - 5. sz. mintaterület: 2001.06.14., $60^{\circ} 2 \%$, TS, +MAL; 2001.05.11., 30", 1\% , TS.

Merodon constans (Rossi, 1794)

1. sz. mintaterület: 2000.07 .21 , 1 1 , TS - 5. sz. mintaterület: 2001.07.05., 2\%, TS.

Merodon nigritarsis Rondani, 1845

4. sz. mintaterület: 2001.07.27., 1ᄋ, TS, +MAL 5. sz. mintaterület: 2001.06.14., 30 1\% , TS, +MAL; 2001.06.15., 10 4o, TS.

Microdon mutabilis (Linnaeus, 1758)

4. sz. mintaterület: 2001.05 .11 , 10", TS - 8. sz. mintaterület: $2000.05 .05 ., 101 \%$, TS, +MAL.

Myathropa florea (Linnaeus, 1758)

1. sz. mintaterület: 2001.09.15., 10, TS - 4. sz. mintaterület: 2001.08 .20 ., 10, TS - 5. sz. mintaterület: 2001.07.05., 10, TS - 6. sz. mintaterület: 2000.05.05., 1申 , TS, Crataegus-on gyüjtve.

Neoascia geniculata (Meigen, 1822)

4. sz. mintaterület: $2000.05 .05 ., 10$, TS - 8. sz. mintaterület: 2002.04.26., 2ᄋ, TS, +MAL.

Neoascia podagrica (Fabricius, 1775)

3. sz. mintaterület: $2001.09 .16 ., 10^{\circ} 5 \%$, TS - 4 . sz. mintaterület: 2001.06 .15 , 1\%, TS - 8. sz. mintaterület: 2001.07.05., 20'4\%, TS, +MAL.

Orthonevra nobilis (Fallén, 1817)

2. sz. mintaterület: $2000.08 .07 ., 1 \sigma$, TS - 4. sz. mintaterület: 2001.07 .27 , 10", TS, +MAL - 8. sz. mintaterület: 2001.07.05., 20*1\%, TS, +MAL.

Paragus finitimus Goeldlin de Tiefenau, 1971

2. sz. mintaterület: 2000.08 .07 ., 2ᄋ, TS - 5. sz. mintaterület: 2001.05.11., TS - Látrányi puszta TT: 1999.07.25., 10', R1.

Paragus haemorrhous Meigen, 1822

1. sz. mintaterület: $2001.04 .26 ., 1 \sigma^{\circ} 3 \%$, PA; 2001.05.29., Iڤ , TS, +MAL - 3. sz. mintaterület: 
2001.09.16., 2థ, TS - 5. sz. mintaterület: 2001.04.26., 10', PA; 2001.07.05., 10̛ 2\% , TS.

Paragus majoranae Rondani, 1857

1. sz. mintaterület: 2001.04.26., 10", PA; 2001.09.15., 3o', TS - 5. sZ. mintaterület: 2002.04.26., 1\%, TS.

Parasyrphus vittiger (Zetterstedt, 1843)

6. sz. mintaterület: $2000.05 .05 ., 2 ᄋ$, TS, Cratacgus-on gyüjtve - 8 . sz. mintaterület: 2002.04.26., 10, TS, +MAL.

Parhelophilus versicolor (Fabricius, 1794)

3. sz. mintaterülct: 2001.09.16., 1६, TS - 4. sz. mintaterület: 2000.05 .05 ., $1 \sigma^{\prime} 1 \%$, TS - 8. sz. mintaterület: 2001.07.05., 10', TS, +MAL.

Pelecocera tricincta Meigen, 1822

2. sz. mintaterülct: 2000.08 .07 , 1 , , TS - 5. sz. mintaterület: 2001.05 .11 , $1 \sigma^{\prime \prime} 1$, , TS.

Pipiza bimaculata Meigen, 1822

4. sz. mintaterület: $2001.05 .11 ., 1 \sigma^{*} 1$ , TS - 5. sz. mintaterület: 2001.06.15., 1\%, TS.

Pipiza festiva Meigen, 1822

5. sz. mintaterület: 2001.06 .14 ., 1९, TS, +MAL 6. sz. mintaterület: $2000.05 .05 ., 1 \sigma^{\prime} 1 \%$, TS, Crataegus-on gyüjtve.

Pipiza noctiluca (Linnaeus, 1758)

4. sz. mintaterület: 2001.08 .20 ., 1\%, TS - 5. sz. mintaterület: 2001.07.05., 1\%, TS.

Pipizella divicoi (Goeldlin de Tiefenau, 1974)

5. sz. mintaterület: 2001.04.26., 20"4\% , PA.

Pipizella viduata (Linnaeus, 1758)

1. sz. mintaterület: 2001.04.26., 10 1\%, PA; 2001.04.26., 10 1\%, RI; 2001.05.29., 40 1\%, TS, +MAL - 3. sz. mintaterület: 2002.04.26., 10", TS - 5 . sz. mintaterület: 2001.04.26., $1 \sigma^{\circ} 5 \%$, PA; 2001.06.14., 7\% 2Q, TS, +MAL - 8. sz. mintaterület: 2001.06.06., 5\% 2ᄋ, TS, +MAL.

Platycheirus albimanus (Fabricius, 1781)

3. sz. mintaterület: $2002.04 .26,10 \%$, TS - 4. sz. mintaterület: 2001.06.15., 1\%, TS.

Platycheirus clypeatus (Meigen, 1822)

2. sz. mintaterület: 2000.08 .07 ., 4 Q , TS - 5. sz. mintaterület: $2001.07 .05 ., 2 \wp$, TS - Látrányi puszta TT: 1999.07.25., 10 4\% , Rl.

Platycheirus fulviventris (Macquart, 1829)

2. sz. mintaterület: $2002.04 .16 ., 1 \sigma^{*} 1 \%$, TS, +MAL - 4. sz. mintaterület: 2001.07.27., 1ф, TS, +MAL - 8. sz. mintaterület: 2000.05.05., 30 1\% , TS, + MAL.

Pyrophaena rosarum (Fabricius, 1787)

3. sz. mintatcrülct: 2001.09.16., 10 1\%, TS - 4. sz. mintaterület: 2001.06 .15 ., 1\%, TS - 9. sz. mintatcrület: $2002.04 .19 ., 2 Q$, TS.

\section{Rhingia campestris Meigen, 1822}

4. sz. mintaterület: 2001.05.11., 2Q, TS - 8. sz. mintaterület: 2000.05.05., 10 1\%, TS, +MAL.

Scaeva pyrastri (Linnaeus, 1758)

2. sz. mintaterület: 2002.04 .16 ., 2 2 , TS, $+\mathrm{MAL}$. 5. sz. mintaterület: $2001.05 .11 ., 1 \sigma 30$, TS - 6. sz. mintaterület: 2001.10 .14 ., 1Q , TS - 8. sz. mintaterület: 2002.04.26., 1\%, TS, +MAL.

Scaeva selenitica (Meigen, 1822)

6. sz. mintaterület: 2000.05 .05$. , 2q, TS, Crataegus-on gyüjtve - $8 . \mathrm{sz}$. mintaterület: 2002.04.19., 1o , TS, +MAL.

Sphaerophoria rueppellii (Wiedemann, 1830)

2. sz. mintaterület: $2000.08 .07 ., 1 \%$, TS.

Sphaerophoria scripta (Linnaeus, 1758)

1. sz. mintaterület: 2001.04.26., 30 4\%, PA; 2001.09.15., 5\% 1\%, TS; 2001.10.05., 10", RI - 3. sz. mintaterület: $2001.09 .16 ., 4 \sigma^{\circ} 7 \%$, TS - 4. sz. minta-

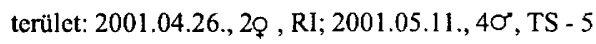
sz. mintaterület: 2001.04.26., 60, $8 \%$, PA; 2001.06.14., 30* 11\%, TS, +MAL; 2001.07.05., 60" 1\%, TS - 6. sz. mintaterület: $2002.04 .26 ., 1 \sigma^{\prime} 4$ \% , TS - 8. sz. mintaterület: 2002.04.26., 30, TS, +MAL Látrányi puszta TT: 1999.07.25., 50 9\%, RI.

Spilomyia diophthalma (Linnacus, 1758)

5. sz. mintaterület: 2001.06.14., 1Q , TS, +MAL; 2001.07.05., 10\% 2\%, TS.

Syritta pipiens (Linnaeus, 1758)

1. sz. mintaterület: $2001.09 .15 ., 3 \sigma^{*} 7 \%$, TS; 2001.10.05., 1\%, RI - 3. sz. mintaterület: 2001.09.16., 1Q, TS - 4. sZ. mintaterület: 2001.08.20., $1 \sigma 4 q$, TS - 5. sz. mintaterület: 2001.07.05., 30, TS - 6. sz. mintaterület 2001.10.14., 4Q, TS - 8. sz. mintaterület: 2001.07.05., 20 1\%, TS, +MAL - Látrányi puszta TT: 1999.07.25., 2\% 3\%, RI.

Syrphus ribesii (Linnacus, 1758)

1. sz. mintaterület: 2001.05 .29 ., 1९, TS, +MAL 5. sz. mintaterület: 2001.04.26., 1Q, PA 2001.07.05., $1 \sigma^{*} 3 \%$, TS - 6. sz. mintaterület: 2001.10.14., 2९, TS -8 . sz. mintaterület: 2002.04.26., 1\%, TS, +MAL.

Syrphus torvus Osten-Sacken, 1875

2. sz. mintaterület: $2002.04 .16 ., 1 Q$, TS - 5. sz. mintaterület: 2001.04.26., $10 \%$ 1\%, PA - 6. sz. mintaterület: 2001.10.14., 2६, TS - 8. sz. mintaterület: 2002.04.19., 1\%, TS, +MAL.

Syrphus vitripennis Meigen, 1822

1. sz. mintaterület: 2001.04.26, 1Q, RI; 2001.09.15., 2\% 1\%, TS - 3. sz. mintaterület: 
2001.09.16, 10 2ᄋ, TS - 5. sz. mintaterület: 2001.04.26., 10", PA; 2002.04.26., 1\% , TS - Látrányi puszta TT: 1999.07.25., 40 2ᄋ , RI.

Tropidia scita (Harris, [1780])

4. sz. mintaterület: 2000.05.05., 10, TS; 2001.07.27., 20\% 4ᄋ , TS, +MAL - 8. sz. mintaterület: 2001.06.06., 1\%, TS, +MAL.

Volucella bombylans (Linnacus, 1758)

4. sz. mintaterület: 2001.07.27., 10, TS, +MAL 5. sz. mintaterület: 2001.06.15., 10 , TS - 8. sz. mintatcrület: 2001.06.06., 2\% 1\%, TS, +MAL.

Volucella pellucens (Linnaeus, 1758)

1. sz. mintaterület: 2001.05.29., 2ᄋ, TS, +MAL 5. sz. mintaterület: 2001.06 .14 , 10, TS, +MAL; 2001.07.05., 10", TS - 8. sz. mintaterület: 2001.06.06., 10 4\% , TS, +MAL.

Xanthandrus comtus (Harris, [1780])

1. sz. mintaterület: 2001.09 .15 ., 1\%, TS - 5. sz. mintaterület: 2001.08 .20 ., 10, TS.

Xanthogramma festivum (Linnaeus, 1758)

1. sz. mintaterülct: 2001.04 .26 ., 1Q, PA - 3. sz. mintaterület: 2002.04 .26 ., 1ф, TS - 5. sz. mintaterület: 2001.04.26., 1@, PA - 8. sz. mintaterület: 2002.04.19., 1\%, TS, +MAL.

Xanthogramma pedisseguum (Harris, [1776])

5. sz. mintaterület: 2001.07 .05 ., 10, TS - 8. sz. mintaterület: $2000.05 .05 ., 2 \wp$, TS, +MAL.

Xylota segnis (Linnacus, 1758)

2. sz. mintaterület: 2000.08 .07 ., 2@, TS - 3. sz. mintaterület: 2001.09 .16 ., 1\%, TS - 4. sz. mintaterület: 2001.08.20., 10, TS - 8. sz. mintaterület: 2001.07.05., 1\%, TS, +MAL.

Xylota sylvarum (Linnaeus, 1758)

5. sz. mintaterület: 2001.06 .15 ., 1\%, TS - 8. sz. mintaterület: 2001.06.06., 1\%", TS, +MAL.

\section{Conopidae}

A család ismert hazai fajainak száma jelenleg 53, ezek csaknem felét (25 taxon) kimutatták Somogyból is (TóTH 2001). A Látrányi puszta TT területén folyó vizsgálatok során eddig faj 13 került elö.

Conops flavipes Linnaeus, 1758

2. sz. mintaterület: $2000.08 .07 ., 2 \sigma^{*} 5 \%$, TS - 5 . sz. mintaterület: 2001.07.05., 10, TS.

Conops quadrifasciatus Degeer, 1776

1. sz. mintatcrület: 2000.07 .21 ., 2 Q , TS - 5. sz. mintaterület: 2001.07.05., 1o, TS.

Conops scutellatus Mcigen, 1804

3. sz. mintaterület: 2001.09.16., 1\%, TS - 4. sz. mintaterület: 2001.06 .15 ., 10, TS - 5. sz. mintaterület: 2001.07.05., 20 3\% , TS.

Dalmannia dorsalis (Fabricius, 1794)

1. sz. mintaterület: 2002.04.26., 10, RI; 2001.09.15., 10, TS - 5. sz. mintaterület: 2001.08.20., 10\%2ᄋ, TS.

Dalmannia punctata (Fabricius, 1794)

1. sz. mintaterület: $2001.04 .26 ., 10 \%$, RI.

Leopoldius coronatus (Rondani, 1857)

1. sz. mintaterület: 2000.07 .21 .21 , , TS - 5. sz. mintaterület: $2001.06 .14 ., 20$, TS, +MAL.

Myopa occulta Meigen, 1824

1. sz. mintaterület: 2001.04.26., 1\%, PA; 2001.05.29., 10 2\% , TS, +MAL - 3. sz. mintaterülct: 2002.04.26., 1\%, TS - 5. sz. mintaterület: 2001.04.26., 10, PA.

Myopa testacea (Linnaeus, 1767)

1. sz. mintaterület: 2001.04.26., 10 10 , PA - 5 . sz. mintaterület: 2001.07 .05 , $10^{*}$, TS - 6. sz. mintaterület: 2002.04.26., 10 1\%, TS.

Physocephala vittata (Fabricius, 1794)

4. sz. mintaterület: 2001.07.27., 1@, TS, +MAL -

5. sz. mintaterület: 2001.08.20., 10, TS.

Sicus ferrugineus (Linnaeus, 1761)

1. sz. mintaterület: 2001.05 .29 ., $4 \sigma^{\circ} 1 \%$, TS, +MAL - 3. sz. mintaterület: 2001.09.16., 1\% , TS - 5. sz. mintaterület: 2001.07.05., 10 2\%, TS.

Thecophora atra (Fabricius, 1775)

1. sz. mintaterület: 2001.09.15., 2q, TS - 2. sz. mintaterület: 2000.08 .07 ., 1\%', TS - 5. sz. mintaterület: 2001.06.14., 10, TS, +MAL.

Thecophora pusilla (Meigen, 1824)

5. sz. mintaterület: $2001.08 .20 ., 1002$, TS - 8 . sz. mintaterület: 2001.06.06., 10', TS, +MAL.

Zodion cinereum (Fabricius, 1794)

4. sz. mintaterület: 2001.06.15., 10", TS - 5. sz. mintaterület: 2001.06 .14 ., 10゙3요, TS, +MAL.

\section{Tephritidae (Trypetidae)}

$\mathrm{Az}$ ismert hazai fajok száma 110 körül van, a Látrányi Puszta Természetvédelmi Területen a hazai fauna csupán mintegy 10\%-a (11 faj) került elő.

Urophora (Euribia) stigma (Loew, 1840)

8. sz. mintaterület: $2000.05 .05 ., 2 Q$, TS, +MAL. Urophora cardui (Linnaeus, 1758)

2. sz. mintatcrülct: $2000.08 .07 ., 1 \sigma^{\circ} 2 \&$, TS.

Urophora solstitialis (Linnaeus, 1758)

1. sz. mintaterülct: 2001.05.29., 40" 1\%, TS, +MAL. Orellia punctata (Schrank, 1781)

4. sz. mintaterülct: 2001.06.15., 10", TS.

Xyphosia miliaria (Schrank, 1781) 
1. sz. mintaterület: $2001.05 .29 ., 30^{\circ} 7 \mathrm{O}$, TS, +MAL.

Dioxyna bidentis (Robineau-Desvoidy, 1830)

2. sz. mintaterület: 2001.07.22., 20", TS.

Campiglossa producta (Loew, 1844)

[syn. Paroxyna (Stylia) tessellata (Locw, 1844)]

2. sz. mintaterület: 2000.08 .07 ., 10", TS.

Oxyna flavipennis (Loew, 1844)

5. sz. mintaterület: 2001.07 .05 ., TS - 8. sz. mintatcrület: 2000.05.05., 30 1\%, TS, +MAL.

Ensina sonchi (Linnacus, 1767)

5. sz. mintaterület: 2001.07.05., 10', TS - 6. sz. mintaterület: 2002.04.26., 10", TS.

Tephritis cometa (Loew, 1840)

4. sz. mintaterület: 2001.06.15., 10", TS.

Trupanea stellata (Fuesslin, 1775)

3. sz. mintaterület: 2002.04 .26 , 10", TS.

\section{Scathophagidae}

A kisebb család jelenleg nyilvántartott hazai fajainak száma 32, melyek közül 7 került elö a Látrányi Puszta Természetvédelmi Területen. Viszonylagos ritkasága miatt a Spathiophora hydromyzina elófordulása érdemel emlitést.

\section{Parallelomma albipes (Fallén, 1819)}

6. sz. mintatcrület: 2002.04.26., 10', TS.

Cordilura pubera (Linnaeus, 1761)

7. sz. mintaterület: 2002.04.20., 2q, TS - 9. sz. mintatcrület: 2002.04.19., 10", TS.

Cleigastra apicalis (Meigen, 1826)

4. sz. mintaterület: $2000.05 .05 ., 10 \%$, TS.

Scatophaga stercoraria (Linnaeus, 1763)

1. sz. mintaterület: 2001.09.15., 10", TS - 3. sz. mintaterület: 2002.04 .26$, , $1 \sigma^{\circ} 5 \%$, TS - 8. sz. mintatcrület: 2000.05.05., $6 \sigma^{\circ} 2 \varrho, \mathrm{TS}, \quad+\mathrm{MAL}$; 2002.04.19., 20\% 1\% , TS, +MAL.

Scatophaga inquinata Mcigen, 1826

1. sz. mintaterület: 2001.05 .29 ., $2 \sigma^{\circ} 8$ \% , TS, +MAL - 2. sz. mintaterület: 2002.04.16., 30", TS, +MAL.

Scatophaga lutaria (Fabricius, 1794)

5. sz. mintaterület: 2002.04.26., 1\%, TS - 8. sz. mintaterület: 2002.04.19., 1ণ̛, TS, +MAL.

Spaziphora hydromyzina (Fallén, 1819)

4. sz. mintatcrület: 2001.06.15., 1Q, TS - 8. sz. mintaterület: 2002.04.26., 1\%, TS, +MAL.

\section{Muscidae}

Nagyobb kétszárnyú család, a hazai fajok száma 210 körülire tehető. A területen folyó vizsgálatok során gyüjtött anyagból 12 fajt sikerült meghatározni.
Graphomyia maculata (Scopoli, 1763)

1. sz. mintaterület: 2001.09.15., 10", TS - 6. sz. mintaterület: 2002.04.26., 1\%, TS.

Lispe melaleuca Loew, 1847

1. sz. mintaterület: $2001.05 .29 ., 4 \sigma^{\circ}, \mathrm{TS}$, +MAL.

Lispe pygmaea Fallén, 1825

2. sz. mintaterület: $2000.08 .07 ., 2 \sigma^{\circ}$, TS.

Hydrotaea armipes (Fallén, 1825)

2. sz. mintaterület: $2002.04 .16 ., 3 \sigma^{\circ} 1$ 1 , TS - 6. sz. mintaterület: 2001.10.14., 10, TS.

Hydrotaea dentipes (Fabricius, 1805)

2. sz. mintaterület: $2002.04 .16 ., 2 \sigma^{\circ}$, TS, +MAL

- 8. sz. mintaterület: 2002.04.19., 10', TS, +MAL.

Muscina levida (Harris, 1780)

2. sz. mintaterület: 2002.04 .16 ., 10", TS - 9. sz. mintaterület: $2002.04 .19 ., 10$, TS.

Mesembrina meridiana (Linnaeus, 1758)

5. sz. mintaterület: $2002.04 .26 ., 100$, TS.

Morellia simplex (Loew, 1857)

2. sz. mintaterület: 2001.07 .22 , 10", TS.

Morellia hortorum (Fallén, 1817)

8. sz. mintatcrület: $2000.05 .05 ., 10$, TS, +MAL.

Musca autumnalis De Geer, 1776

1. sz. mintatcrülct: 2001.05 .29 , $5 \sigma^{\circ} 4 Q$, TS, +MAL - 5. sz. mintaterület: 2001.08.20., 2९, TS - 6 . sz. mintaterület: $2001.10 .14 ., 3 \%$, TS.

Musca vitripennis Meigen, 1826

1. sz. mintaterület: 2001.09 .15 ., 3o , TS - 5. sz. mintaterület: 2002.04 .26 ., 2 Q , TS - 6. sz. mintaterület: 2001.10.14., $10^{\circ}$ 1\%, TS.

Stomoxys calcitrans (Linnacus, 1758)

1. sz. mintaterület: 2001.09 .15 ., 1\%, TS - 2. sz. mintaterület: 2000.08 .07 ., 1Q , TS - 4. sz. mintaterület: 2001.08.20., 10, TS.

\section{Calliphoridae}

$\mathrm{Az}$ ismert 56 hazai fajból 9 előfordulására van adatunk a természetvédelmi területen. Közülük a föleg hegyvidékekre jellemző Cynomya mortuorum előkerülése emelhetö ki.

Calliphora vicina Robineau-Desvoidy, 1830

5. sz. mintaterület: 2002.04 .26 ., 1\%, TS - 8. sz. mintaterület: $2000.05 .05 ., 103 \%$, TS, +MAL. 1830)

Melinda viridicyanea (Robincau-Desvoidy,

1. sz. mintaterülct: 2001.05 .29 ., $3 \sigma^{\circ} 1 \%$, TS, +MAL.

Bellardia viarum (Robineau-Desvoidy, 1830)

2. sz. mintaterület: $2002.04 .16 ., 3 \sigma^{\circ} 1 \%$, TS,

+MAL - 6. sz. mintaterület: 2001.10.14., 10", TS.

Cynomya mortuorum (Linnacus, 1761)

2. sz. mintaterület: 2001.07 .22 ., 10", TS. 


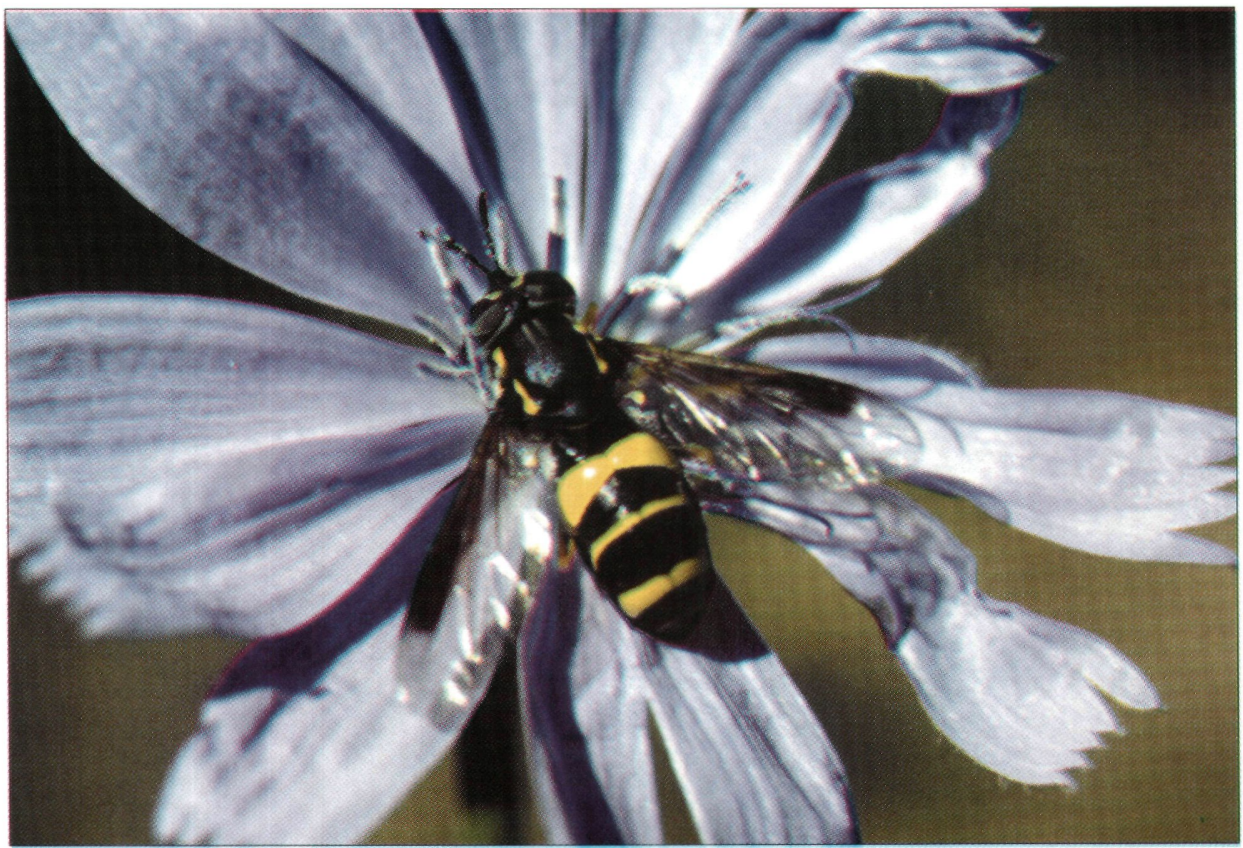

10. ábra: Chrysotoxum bicinctum

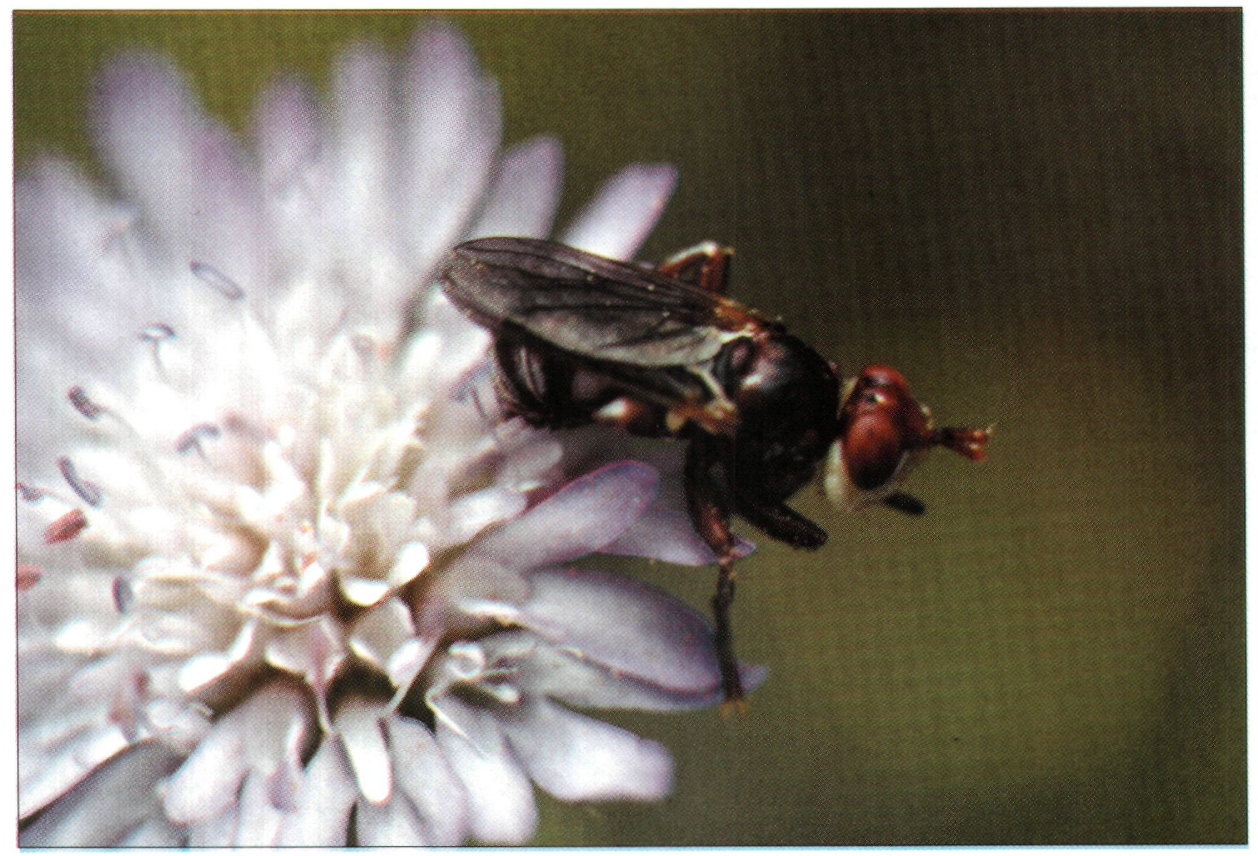

9. ábra: Sicus ferruginus 


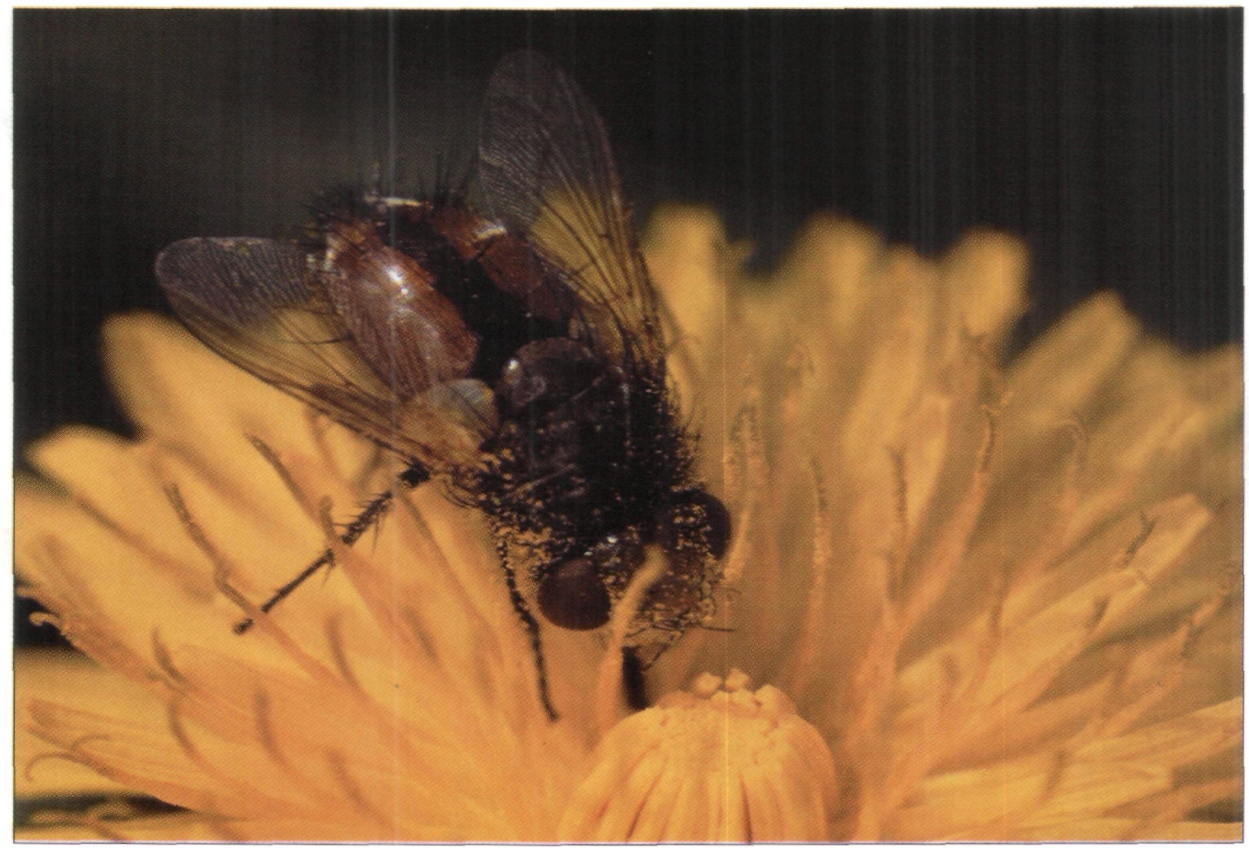

11. ábra: Gonia vacina

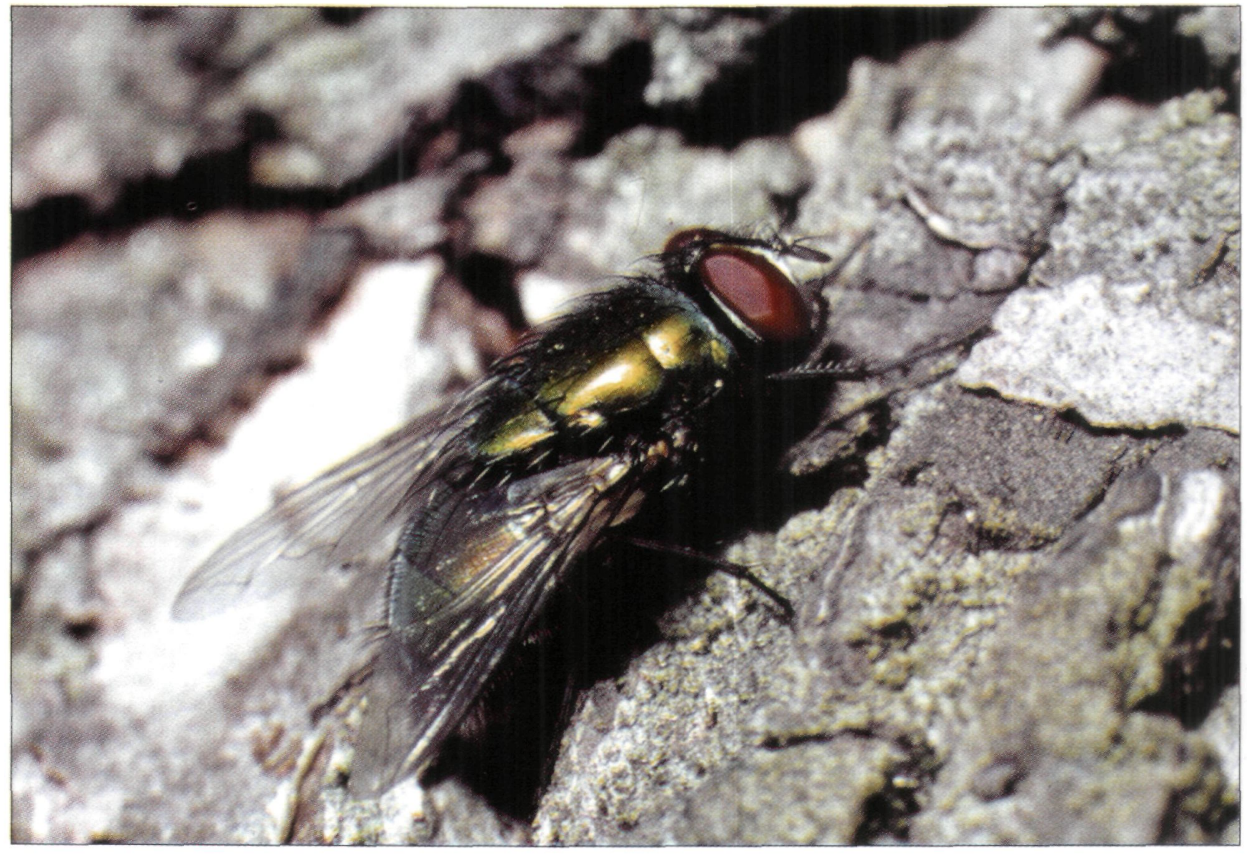

12. ábra: Lucilla caesar 
Lucilia caesar (Linnaeus, 1758)

1. sz. mintaterület: 2001.09 .15 , 10, TS - 2. sz. mintatcrület: 2002.04.16., 30"5o , TS - 3. sz. mintaterület: $2001.09 .16 ., 2 \sigma^{\circ} 3 \wp$, TS - 6. sz. mintaterülct: 2002.04.26., 3o", TS.

Lucilia sericata (Meigen, 1826)

4. sz. mintaterület: $2001.06 .15 ., 3 \sigma^{\prime \prime} 1 \%$, TS - 5 . sz. mintaterület: 2002.04.26., 10", TS.

Lucilia silvarum (Meigen, 1826)

1. sz. mintaterület: 2001.05 .29 ., $2 \sigma^{\circ} 6 \%$, TS, +MAL - 6. sz. mintaterület: 2002.04.26., 10", TS.

Pollenia rudis (Fabricius, 1786)

1. sz. mintaterület: 2001.09 .15 ., 30 5o , TS - 2. sz. mintaterület: 2002.04 .16 ., $10^{\circ} 4$ ᄋ , TS - 3. sz. mintaterület: 2002.04 .26 ., 10", TS - 5. sz. mintaterület: 2001.06.14., 20 7\% , TS, +MAL - 6. sz. mintaterület: $2001.10 .14 ., 2 \sigma 5$, , TS - 8. sz. mintaterület: 2002.04.19., 3テ 1\%, TS, +MAL.

Pollenia similis (Jacentkovsky, 1942)

2. sz. mintatcrület: 2000.08 .07 ., 10, TS.

\section{Sarcophagidae}

A nagyobb Diptera családok közé tartoznak, mintegy 130 hazai taxonjukat tartják nyilván. A Látrányi Puszta Természetvédelmi Területen is gyakoriak, de a meghatározás nehézségei miatt egyelöre csak 7 fajukat soroljuk fel. Két fajukról (Taxigramma heteroneurum, Paragusina elegantula) érdemes megjegyezni, hogy elsősorban az alföldi homokos területekre jellemző elemek.

Taxigramma heteroneurum (Meigen, 1830)

1. sz. mintaterület: 2001.05.29., 30", TS, +MAL.

Paragusina elegantula (Zetterstedt, 1844)

2. sz. mintatcrület: 2001.07.22., 10", TS.

Ravinia striata (Fabricius, 1794)

2. sz. mintaterület: 2002.04.16., 10", TS - 8. sz. mintaterület: 2002.04.26., 10", TS, +MAL.

Pterella melanura (Mcigen, 1826)

6. sz. mintaterület: 2002.04 .26 , 10", TS - 8. sz. mintaterülct: 2002.04.26., 3\%", TS, +MAL.

Parasarcophaga albiceps (Mcigen, 1826)

5. sz. mintaterület: 2002.04.26., 10", TS.

Sarcophaga africa (Wiedemann, 1826)

[syn. Bercaea haemorrhoidalis (Fallén, 1816)]

4. sz. mintaterület: 2001.08 .20 ., 10", TS.

Sarcophaga variegata (Scopoli, 1763)

(syn. Sarcophaga carnaria Linnaeus, 1758)

I. sz. mintaterület: 2001.05.29., 50', TS, +MAL - 3. sz. mintaterület: 2002.04 .26 ., 10", TS - 6. sz. mintaterület: $2001.10 .14 ., 20$, TS.

\section{Gasterophilidae}

Kis család, a hazai fajok száma 5, a vizsgált területen csak a közönséges lóbagócs került elő.

Gasterophilus intestinalis (De Geer, 1776)

2. sz. mintaterület: 2002.04 .16 , 1\%, TS.

\section{Oestridae}

Kis fajszámú család, a 4 ismert hazai faj közül csak a közönsćges juhbagócsot sikerült megtalálni a Látrányi puszta TT kutatása során.

Oestrus ovis Linnaeus, 1758

1. sz. mintaterület: 2001.05.29,, 1९, TS, +MAL.

\section{Hippoboscidae}

Magyarországon 11 fajuk előfordulásáról tudunk, két gyakoribbat a természetvédelmi terület kutatása során is megtaláltunk.

Hippobosca equina Linnaeus, 1758

5. sz. mintaterület: 2002.04.26., 10", TS.

Lipoptena cervi (Linnacus, 1758)

2. sz. mintaterület: 2002.04.16., 10, TS, +MAL.

\section{Tachinidae}

Nagy kétszárnyú család, Magyarországon 433 fajuk előfordulásáról tudunk. Lárváik kizárólag belső élösködők, nagy jelentőségük van a kártevők pusztításában. Somogy megyéböl eddig 174 fajt közöltek (Tóth 2001). A Látrányi Puszta Természetvédelmi Terület kutatása során elökerült 47 faj nem sokkal haladja meg a haza fauna $10 \%$-át. További rendszeres gyüjtések eredményeképpen valószínüleg többszörösére nőne a fajszám.

Acemya acuticornis (Meigen, 1824)

2. sz. mintaterület: $2002.04 .16 ., 20^{\circ} 1 \%$, TS, +MAL.

Actia crassicornis (Meigen, 1824)

1. sz. mintaterület: $2000.07 .21 ., 10 "$, TS.

Athrycia trepida (Meigen, 1824)

5. sz. mintaterület: 2001.06 .14 ., $2 \sigma^{\circ} 2 \bigcirc$, TS, +MAL.

Atylostoma tricolor (Mik, 1884)

1. sz. mintaterület: 2001.05.29., 3\%, TS, +MAL.

Bessa parallela (Meigen, 1824)

5. sz. mintaterület: 2002.04.26., 2Q, TS.

Blepharipa pratensis (Meigen, 1824)

8. sz. mintaterület: 2002.04.19., 1ᄋ , TS, +MAL. Blondelia nigripes (Fallén, 1810) 
4. sz. mintaterület: 2001.06.15., 20*, TS - 6. sz. mintaterület: 2001.10 .14 ., 10*3o, TS - 8. sz. mintaterület: 2001.06.06., 2ᄋ , TS, +MAL.

Carcelia tibialis (Robineau-Desvoidy, 1863)

4. sz. mintaterület: 2001.07.27, 10, TS, +MAL - 5. sz. mintaterülct: 2001.06.14., 20'1\%, TS, +MAL.

Ceromasia rubrifrons (Macquart, 1834)

2. sz. mintaterület: $2000.08 .07 ., 1 \sigma^{\circ}$, TS.

Clytiomya continua (Panzer, 1798)

1. sz. mintaterület: 2001.09 .15 ., 10", TS - 8. sz. mintaterület: 2002.04.19., 1\%, TS, +MAL.

Compsilura concinnata (Meigen, 1824)

4. sz. mintaterület: 2001.05 .11 ., 3o, TS - 6. sz. mintaterület: 2001.10 .14 ., $1 \sigma^{\circ}$, TS - 8. sz. mintaterület: 2002.04.19., 20, TS, +MAL.

Cylindromyia bicolor (Olivier, 1812)

1. sz. mintaterület: 2001.09.15., 2 \%, TS - 3. sz. mintaterület: 2002.04.26., 10, TS.

Cylindromyia brassicaria (Fabricius, 1775)

1. sz. mintaterület: 2000.07 .21 ., 10", TS - 6. sz. mintaterület: $2001.10 .14 ., 2 \%$, TS.

Cyzenis albicans (Fallén, 1810)

1. sz. mintaterület: $2001.05 .29 ., 10^{\circ} 4 \mathrm{o}$, TS, +MAL - 8. sz. mintaterület: 2002.04.26., 10", TS, +MAL.

Dexia rustica (Fabricius, 1775)

2. sz. mintaterülct: 2000.08 .07 ., 1ф , TS.

Dinera ferina (Fallćn, 1817)

3. sz. mintatcrület: 2001.09.16., 10", TS - 4. sz. mintaterület: 2001.08 .20 ., 1\%, TS.

Ectophasia crassipennis (Fabricius, 1794)

3. sz. mintaterület: 2002.04 .26 ., 10, TS - 5. sz. mintaterület: 2001.05.11., 20 10, TS.

Ectophasia oblonga (Robineau-Desvoidy, 1830)

1. sz. mintaterület: 2001.09.15., 10, TS - 4. sz. mintaterület: 2001.06.15., 10, TS.

Eliozeta helluo (Fabricius, 1805)

2. sz. mintaterület: 2002.04.16., 1९, TS, +MAL.

Elomya lateralis (Mcigen, 1824)

5. sz. mintaterület: 2002.04 .26 , 19 , TS.

Ernestia rudis (Fallén, 1810)

2. sz. mintaterület: $2000.08 .07 ., 10$, TS.

Exorista larvarum (Linnacus, 1758)

4. sz. mintaterülct: 2001.05.11., 10 1\%, TS - 6 . sz. mintaterület: 2002.04 .26 , 1\%, TS

Gonia vacua Meigen, 1826

1. sz. mintatcrület: 2001.05.29., 20 1\%, TS, +MAL - 2. sz. mintaterület: 2002.04.16., 1ఠ", TS - 5 . sz. mintaterület: 2001.05.11., 2Q, TS.

Gymnosoma rotundata (Linnaeus, 1758)

3. sz. mintaterület: $2001.09 .16 ., 10^{\circ}$, TS - 4. sz. mintaterület: 2001.06 .15 ., 1\%, TS - 6. sz. mintaterület: 2001.10.14., 10', TS.
Leskia aurea (Fallén, 1820)

8. sz. mintaterület: 2002.04.19., 1९, TS, +MAL.

Linnaemya picta (Mcigen, 1824)

2. sz. mintaterület: 2001.07.22., 20", TS.

Linnaemya vulpina (Fallén, 1810)

1. sz. mintaterület: 2001.09.15., 20", TS - 2. sz. mintaterület: 2000.08.07., 10", TS.

Macquartia tenebricosa (Mcigen, 1824)

2. sz. mintaterület: 2002.04.16,, 20, TS, +MAL

- 8. sz. mintaterület: 2001.06.06., 10', TS, +MAL.

Masicera silvatica (Fallén, 1810)

2. sz. mintaterület: 2001.07.22., 10", TS.

Meigenia mutabilis (Fallén, 1810)

3. sz. mintaterület: 2001.09.16., 20', TS - 4. sz. mintaterület: 2001.08 .20 ., $3 \sigma^{\circ} 8$ o , TS - 6. sz. mintaterület: 2001.10.14., 1९, TS.

Microsoma exigua (Mcigen, 1824)

2. sz. mintaterület: 2002.04.16., 1\%, TS, +MAL.

Nemorilla floralis (Fallćn, 1810)

6. sz. mintaterülct: 2002.04.26., 10", TS - 8. sz. mintaterület: 2001.06.06., 20 1\%, TS, +MAL.

Pales pavida (Mcigen, 1824)

4. sz, mintaterület: 2001.05.11., 20, TS - 5. sz. mintaterület: 2001.06 .14 ., 2ᄋ, TS, +MAL -8. sz. mintaterület: $2002.04 .19 ., 1 \sigma$, TS, +MAL.

Peribaea tibialis (Robineau-Desvoidy, 1851)

1. sz. mintaterület: $2000.07 .21 ., 1 \sigma 2 \%$, TS - 3 .

sz. mintaterület: 2001.09.16., 10, TS.

Phania incrassata Pandellé, 1894

1. sz. mintaterülct: 2001.05 .29 ., $1 \sigma^{\prime} 1 Q$, TS, +MAL - 8. sz. mintaterület: 2001.06.06., 10", TS, +MAL.

Phasia barbifrons (Girschner, 1887)

4. sz. mintaterület: $2001.06 .15 ., 10^{\circ}$, TS.

Phorocera assimilis (Fallén, 1810)

2. sz. mintaterület: 2001.07 .22 , 1\%, TS - 4. sz. mintaterület: $2001.05 .11 ., 10 \%$,TS.

Phryxe vulgaris (Fallén, 1810)

2. sz. mintatcrület: $2000.08 .07 ., 3 \sigma 1$ \% , TS - 3 . sz. mintaterület: 2001.09 .16 ., $1 \sigma^{\circ} 4 Q$, TS - 4. sz. mintaterület: 2001.05.11., 20", TS.

Platymya fimbriata (Mcigen, 1824)

4. sz. mintaterület: $2001.08 .20,1 \sigma^{\circ}$, TS - 5. sz. mintaterület: $2001.05 .11 ., 20^{\circ} 1 \odot$, TS.

Siphona geniculata (De Geer, 1776)

8. sz. mintaterület: 2002.04.26, 10", TS, +MAL. Smidtia conspersa (Mcigen, 1824)

5. sz. mintatcrülct: 2002.04.26., 10, TS.

Tachina fera (Linnacus, 1761)

1. sz. mintaterület: 2001.05 .29 ., $1 \sigma^{* 7 \%}$, TS, +MAL - 3. sz. mintaterület: 2001.09.16., 30 7\%, TS - 5. sz. mintaterület: 2001.06.14., 3\% , TS, +MAL - 8. sz. mintaterület: 2001.06.06., 1\%, TS, +MAL. 
Tachina nupta (Rondani, 1859)

2. sz. mintaterület: 2000.08 .07 ., 100, TS - 8. sz. mintaterület: 2001.06.06., $2 \sigma^{\circ} 10$, TS, +MAL.

Voria ruralis (Fallén, 1810)

5. sz. mintaterület: 2001.05 .11 ., 10", TS - 6. sz. mintaterület: 2001.10 .14 ., 1\% , TS - 8. sz. mintaterület: 2000.05.05., 1\%, TS, +MAL.

Winthemia variegata (Meigen, 1824)

8. sz. mintaterület: 2002.04.26., 10", TS, +MAL.
Zenillia libatrix (Panzer, 1798)

1. sz. mintaterület: 2000.07 .21 , 10", TS - 5. sz. mintaterület: 2002.04 .26 ., $1 \sigma^{\prime} 2 \propto$, TS - 8. sz. mintaterület: 2001.06.06., 2ᄋ , TS, +MAL.

Zophomyia temula (Scopoli, 1763)

5. sz. mintaterület: 2001.05.11., 20", TS - 6. sz. mintaterület: 2002.04.26., 1\% , TS - 8. sz. mintaterület: $2000.05 .05 ., 10 \% 1 \%$, TS, +MAL.

\section{Természetvédelmi javaslat}

Hazánkban jelenleg egyetlen kétszárnyú faj sem áll törvényes védelem alatt. Ez azonban nem jelenti azt, hogy a család ne tartalmazna természetvédelmi szempontból jelentős taxonokat. A Látrányi Puszta Természetvédelmi Terület Diptera-faunájának fennmaradása érdekében elsősorban a terület homokhátjain kifejlödött homokpusztai gyepek jelenlegi formájában való megőrzése lehetne a legfontosabb feladat. A homokhátakon számos olyan növény fejlődik, melynek virágja (virágpor, nektár) fontos tápláléka sok zengőlégynek (Syrphidae), pöszörlégynek (Bombyliidae), stb. Ilyen növény pl. a nagy állományokat alkotó pusztai kutyatej (Euphorbia seguieriana), mely a fó tápláléka a terület egyik érdekes, szinte kizárólag löszös és homokos élöhelyekhez kötődő zengőlegyének (Merodon clavipes), de mellette sok más fajnak is. Vannak természetesen föleg a homokhoz és kevésbé a növényzethez kötődő fajok is.

Mindenképpen meg kellene akadályozni a homokhátak esetleges erdősítését, ami föleg az árnyékolás miatt teljesen megváltoztatja a környezeti feltételeket. Eltünik a pusztai növényzet, ennek pedig elkerülhetetlen következménye a fauna megváltozása, melynek következtében elsősorban a területre jellemzö, országosan is ritkának minősülö fajok tünhetnek el.

Hasonló csak más természetü veszélyt jelent a faunára a gyep esetleges feltörése, amit szintén számos faj eltünését eredményezné.

Ugyancsak meg kellene akadályozni a területen folyó illegális szemétlerakást. Különösen sok szemét található az 5. sz. mintaterülettöl kissé É-ra lévő füzbokros mélyedésben, ahová a fỏútról egy kocsiút vezet, így jármüvekkel hordják oda a szemetet.

\section{Irodalom}

ÁBRAHÁM L. szcrk. (2001): Somogy fauna katalógusa - Nat. Somogy., 1: 1-494.

MAJER J. (2001a): Somogy megye kószalcgycinck katalógusa (Diptera: Rhagionidae) - Nat. Somogy., 1: 391 -392. MAJER J. (2001b): Somogy megye Xylomidae katalógusa (Diptera: Xylomidac) - Nat. Somogy., 1: 393-394. MAJER J. (2001c): Somogy megye katonalegyeinck katalógusa (Diptera: Stratiomyidae) - Nat. Somogy., 1: $395-397$. MAJER J. (2001d): Somogy megye bögölyeinek katalógusa (Diptera: Tabanidacidae) - Nat. Somogy., 1: 399-404. Tóтн S. (2001a): Somogy megye lószúnyogjainak katalógusa (Diptera: Tipulidae) - Nat. Somogy., 1: 377-379. Tо́тH S. (2001b): Somogy megye iszapszúnyogjainak katalógusa (Diptera: Limoniidac) - Nat. Somogy., 1: 381 -382. TóTH S. (2001c): Somogy megye csípőszúnyogjainak katalógusa (Diptera: Culicidac) - Nat. Somogy., 1: 383-388 То́тн S. (2001d): Somogy megye töröslegyeinek katalógusa (Diptera: Therevidae) - Nat. Somogy., 1: 409-410. Tóтн S. (2001c): Somogy megye pöszörlegycinck katalógusa (Diptera: Bombyliidae) - Nat. Somogy., 1:411-412. Tо́тн S. (2001 f): Somogy megyc zengölegyeinek katalógusa (Diptera: Syrphidae) - Nat. Somogy., 1: 413-422. Tóтн S. (2001 g): Somogy megye fejeslegycinck katalógusa (Diptera: Conopidae) - Nat. Somogy., 1: 423-424. TóтH S. (2001h): Somogy megye fürkészlcgyeinek katalógusa (Diptera: Tachinidac) - Nat. Somogy., 1: $427-434$. Tóтн S. (2002): Adatok Somogy megyc kétszárnyú (Diptera) faunájához - Nat. Somogy., 3: 63-88. 


\section{Data to the fly fauna of the Látrányi Puszta Nature Conservation Area (Diptera)}

\section{SÁNDOR TÓTH}

During the basic research conducted in the protected area between 2000 and 2002, 298 taxon were reported belonging to 23 Diptera families. Most of the two-winged species of the examined area are common and regular species occurring in most of Hungary. However, few of the taxon are relatively rare and some are typical to the sandy steppes to some extent. This can be the explanation why the two-winged fauna of the area shows similarities to the fauna of the Barcsi Juniper Woodland in the Transdanubia, the juniper and pine woodland near Fenyöfö, and to some of the sandy grasslands of the Great Plain (for example the Kiskunsag).

This similarity is suggested by the presence of the following species: Merodon clavipes, Callicera aenea, Pelecocera tricincta and Spilomyia diophthalma among the hover-flies (Syrphidae), Micomitra stupida, Systoechus gradatus and Villa humilis among bee-flies (Bombyliidae), Cliorismia ardea among the stiletto flies (Therevidae), or Taxigramma heteroneurum and Paragusina elegantula among flesh flies (Sarcophagidae) and Nephrotoma scurra crane-flies (Tipulidae).

Among the two-winged species developing in wet habitatats, Ptychoptera albimana false crane-flies (Ptychopteridae), a Chaoborus flavicans phantom gnats (Chaoboridae), and Spathiophora hydromyzina yellow dung flies (Scathophagidae) are worth mentioning due to their rare occurrance. 